\title{
THE DEMOCRACY OF NATURE
}

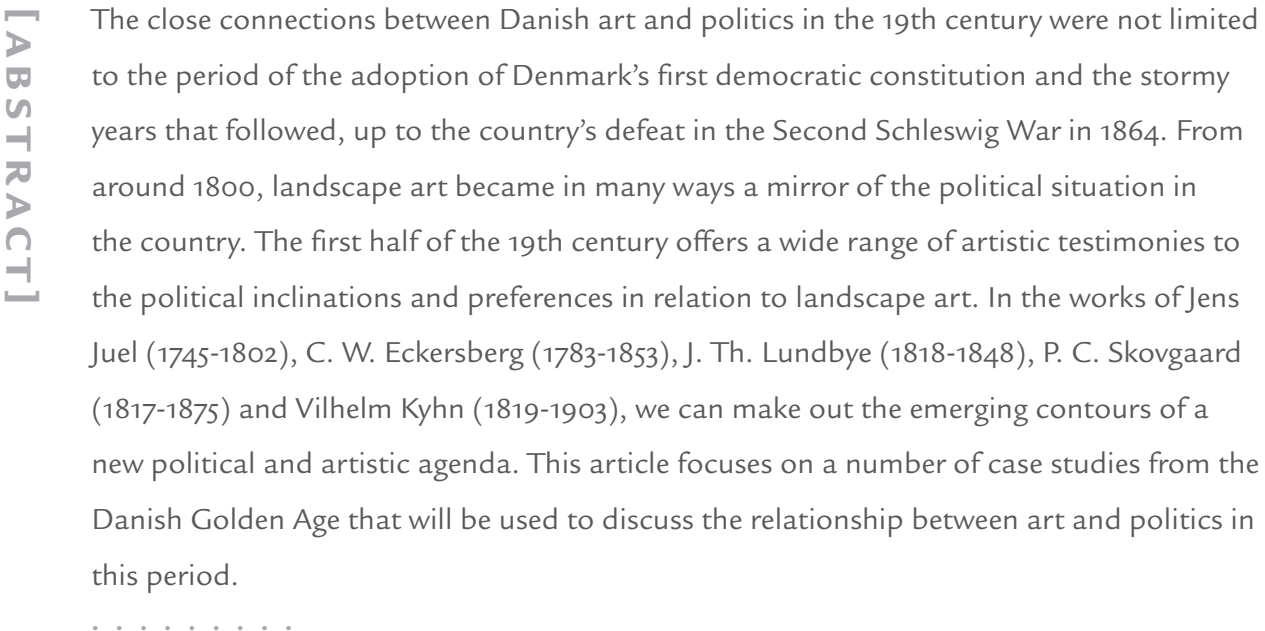

K E Y W O R D S Landscape art, politics, J. Th. Lundbye, P. C. Skovgaard, Jens Juel.

\section{Political Landscapes}

You would like to know what works I have in progress; I only gather material for works; I paint chiefly around and about, inside the forest; there are wonderful tall trees that stand individually, or gather into voluminous groups and closely-packed masses, now and then with a view, between the trunks, of the lovely Nærum Valley; it is especially lovely in the afternoon; now there is fine green grass for the forest floor, now great clusters of raspberries, ferns and willow-herb in bloom, and finally charming, light young forest; this is more than can be painted, so it is no matter if other countries have even more beautiful landscapes. (Skovgaard, Letter to Orla Lehmann)

This is an extract from a letter written by the painter P. C. Skovgaard (1817-1875) to the National-Liberal politician Orla Lehmann (1810-1870) in 1853. The surviving correspondence between the two is one of many examples of the extensive connections between artists and politicians at a time when the modern nationstate of Denmark was being established and the struggle for a democratic constitution was taking place. However, the close connections between art and politics were not limited to the period around the adoption of Denmark's first demo- 
cratic constitution and the stormy years that followed, up to the country's defeat in the Second Schleswig War in 1864. From around 1800, landscape art became in many ways a mirror of the political situation in the country. The first half of the nineteenth century offers a wide range of artistic testimonies to the political inclinations and preferences of landscape artists. In the works of Jens Juel (17451802), C. W. Eckersberg (1783-1853), J. Th. Lundbye (1818-1848), P. C. Skovgaard (1817-1875) and Vilhelm Kyhn (1819-1903), we can make out the emerging contours of a new political and artistic agenda, and in the next few pages a number of case studies of landscape painters from the Danish Golden Age will be used to discuss the relationship between art and politics in this period. ${ }^{1}$

\section{Patriotic Idylls and Political Allegories}

Jens Juel is one of the most important Danish portrait artists; he worked at the end of the 18th century, up to the year 1800 . A lesser-known but in this context important side of Juel's work is that he also painted 75 landscapes (HvidbergHansen, Miss and Zacho 10), mostly of Danish subjects, though a smaller number were inspired by the long journey Juel made in the years 1772-1779. Besides stays at the classic destinations in Rome and Naples, the journey took Juel to Switzerland, where he became part of a milieu that cultivated a philosophical discourse deriving from Rousseau. In this discourse, the qualities of human beings in the state of nature were a key part of the agenda. This is reflected by Juel in a number of works where the subject of his portrait are shown in natural surroundings: these are not simply figure portraits, since the surrounding landscape is also portrayed. One example of this is Baroness Matilda Guiguer de Prangins in her park at Lake Geneva (1779, ill. 1), in which the young baroness is shown in the sheltering context of the foliage above, in her garden, with a wide view of Lake Geneva and her property in the background.

This is not simply a portrait, it is also a detailed rendering of nature; it was undoubtedly produced with inspiration from the milieu of thinkers of which Juel became a part during his stay in Switzerland. Fêted as Juel was as a portrait painter, this genre bore within it the landscape art that Juel claimed to work with 'for pleasure and in idle moments' (Weinwich; Kold 44).

Measured against the large numbers of his portraits, Juel's landscapes represent only a small proportion of the oeuvre, but there is still something conspicuously underplayed in his description of his activity as a landscape painter. This is probably because of the status of landscape painting in the official genre hierarchy of the time, which still favoured history painting. However, this was a hierarchy that was soon to undergo substantial changes, prompted to a great extent by the art requirements of a burgeoning bourgeoisie that was no longer demanding allegorical, historical narratives but preferred the landscape genre. A few years after returning from his long journey abroad, Juel painted View from Sorup of Fredensborg Castle (ill. 2).

From the stylized, framing Baumschlag of the foreground with the resting red deer, we look out over the landscape to Fredensborg Castle in the distance. 


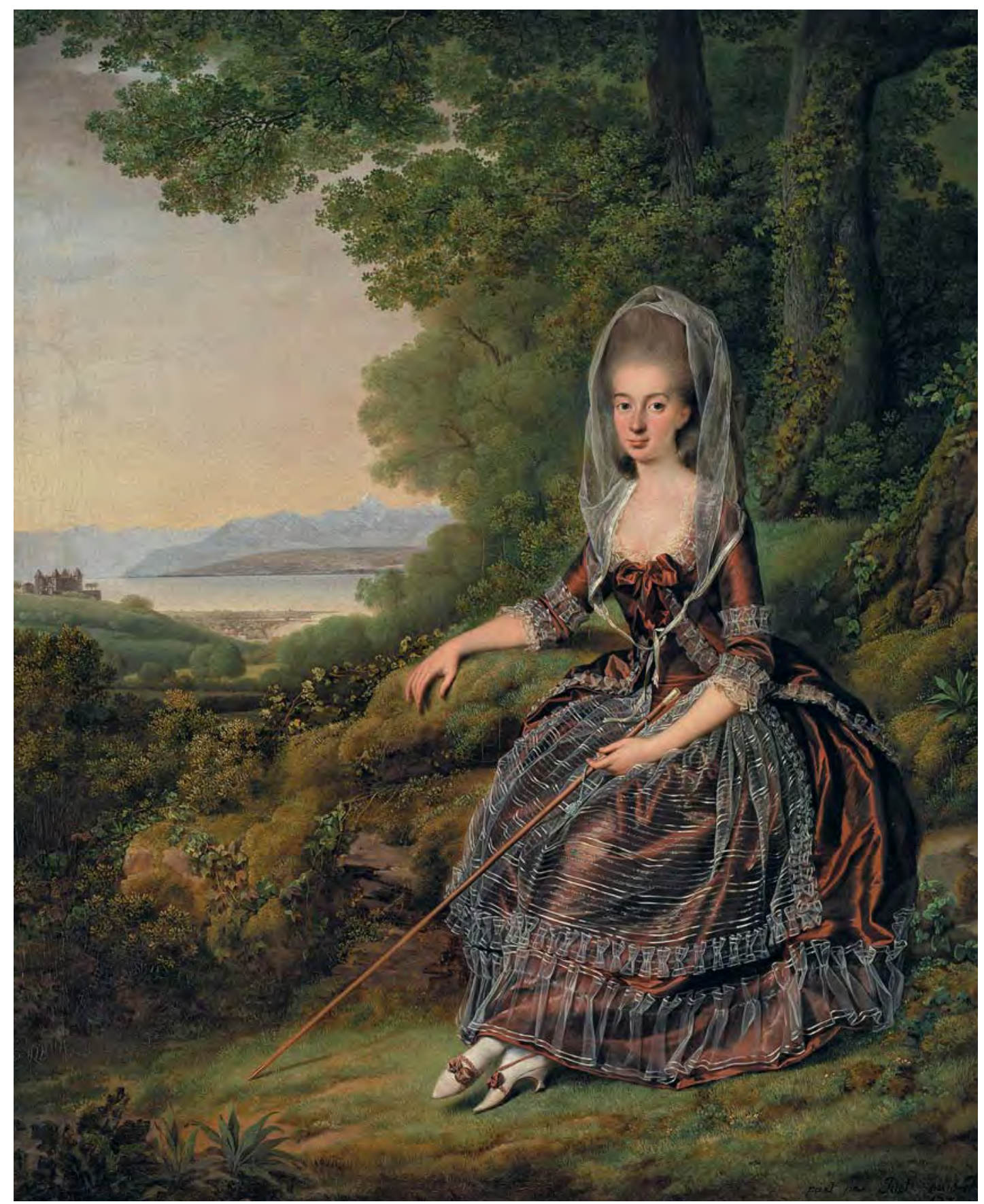

III. 1 [Jens Juel, Baroness Matilda Guiguer de Prangins in her park by Lake Geneva, 1779.

Oil on canvas, $86.5 \times 72 \mathrm{~cm}$. Statens Museum for Kunst, Copenhagen, photo SMK Foto]

There is laundry bleaching and the humble figures of peasants filling the middle ground with busy patriotic activity, which is discreetly accentuated by the smoke that billows from the chimney of a small house that can be glimpsed in the middle ground of the picture. The patriotic citizen was willing to make an effort for his fatherland; this was not necessarily the same as the country in which he was born - but more on this later.

This painting is normally assumed to have been executed in 1782 (Fabienke and Oelsner 34). If we believe this date, we can note that the royal property that 


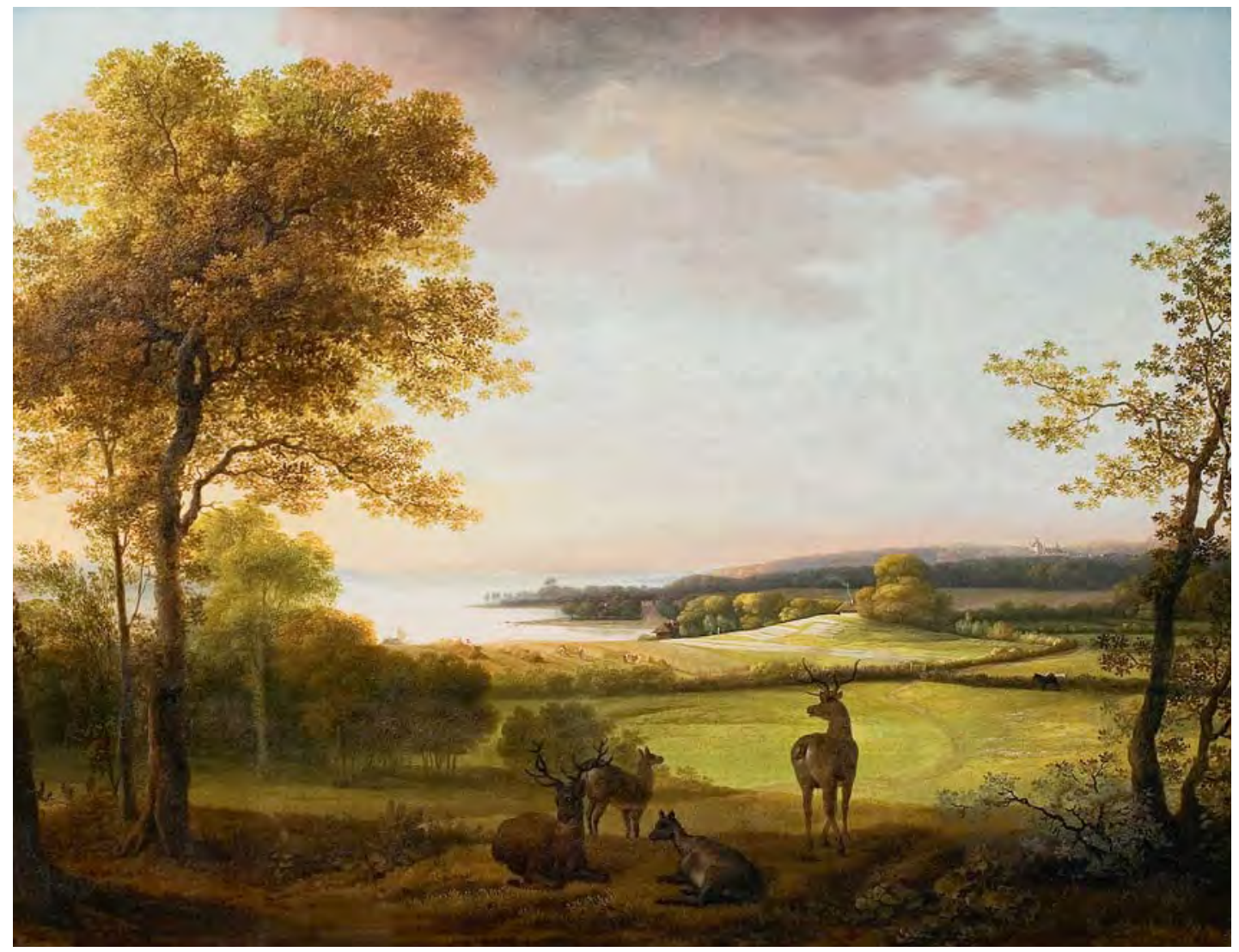

III. 2 [Jens Juel, View from Sørup of Fredensborg Castle, c. 1782.

Oil on canvas, 60.6 x 77.5 cm. Fuglsang Kunstmuseum, Toreby, photo Ole Akhøj]

merges seamlessly with the productive universe of nature in the background must have been occupied by the Dowager Queen Juliane Marie (1729-1796), who shared the real power in the country with Ove Høegh-Guldberg (1731-1808) after the fall of Johann Friedrich Struensee (1737-1772). But the prevailing patriotic discourse did not limit the unified national sense of belonging to a specific place. Instead, it was grounded in the citizenship concept, where the crucial factor was the duties and rights the individual had in relation to the State, with the King as its the highest authority. ${ }^{2}$

Despite the explicit mention of the geographical locality in the title of this painting, Juel was not yet working in the genre of the place-specific landscape study. The need to produce such landscape studies was impressed on C. W. Eckersberg's future pupils and their immediate successors, albeit with a generalized characterization of the type. Juel's work was painted just seven years before the great agrarian reforms decisively changed the Danish landscape. Nevertheless, the discreet positioning of the castle in the periphery of the painting seems to point to a development which, with the agrarian reforms as the economic starting point, not only transformed the Danish landscape forever, but was also of 


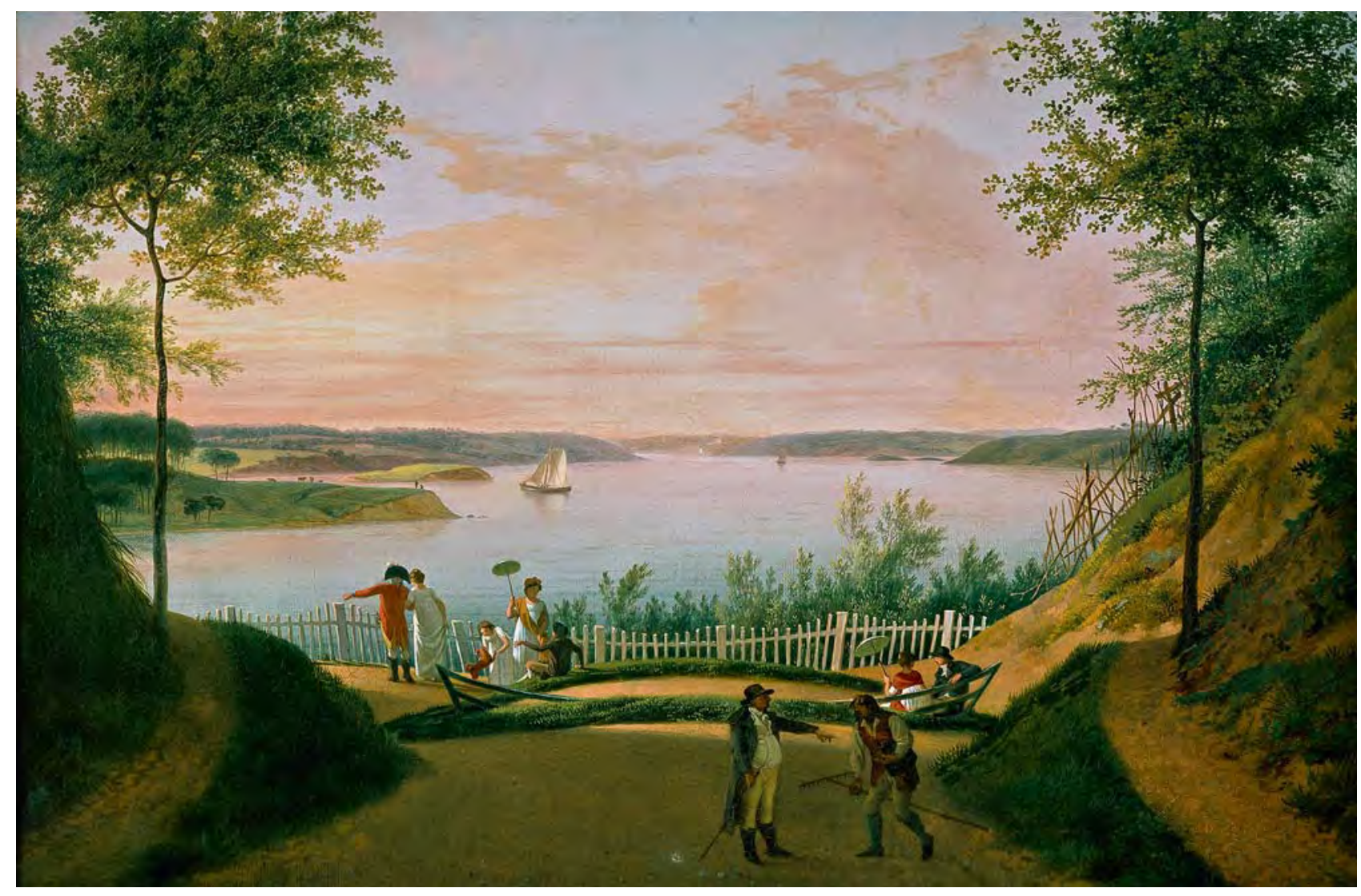

III. 3 [Jens Juel, View across the Little Belt from Hindsgavl on Funen, c. 1800.

Oil on canvas, $42 \times 62.5 \mathrm{~cm}$. Thorvaldsens Museum, Copenhagen, photo Hans Petersen]

crucial importance to the phasing-out of absolutism and feudalism in favour of a democratic constitution. Juel, who was a member of several patriotic societies (Hvidberg-Hansen, Miss and Zacho 79ff) and well versed in the theoretical literature of the agrarian reforms (Kold 46), was not artistically content to perpetuate a moderate patriotic discourse.

In at least one suite of pictures, he gave voice to a more radical message through his landscape painting. This can be seen in the works View across the Little Belt from Hindsgavl on Funen (c. 180o, ill. 3) and View across the Little Belt from a bill at Middelfart (c. 180o, ill. 4), which depict scenes from before and after the abolition of adscription respectively.

In the first painting, the seigneurial punishment of the peasant takes place in a highly symmetrical and regulated natural universe where the slender trees and the bare slopes suggest that this could be a newly established garden complex. This garden ends where a white fence marks the transition to the wilder, unregulated landscape on the other side, symbolized by a lush irregular hedgerow. The other work is a different matter. Here, the symmetrical regulation of both landscape and human beings has given way to a conception of landscape that 


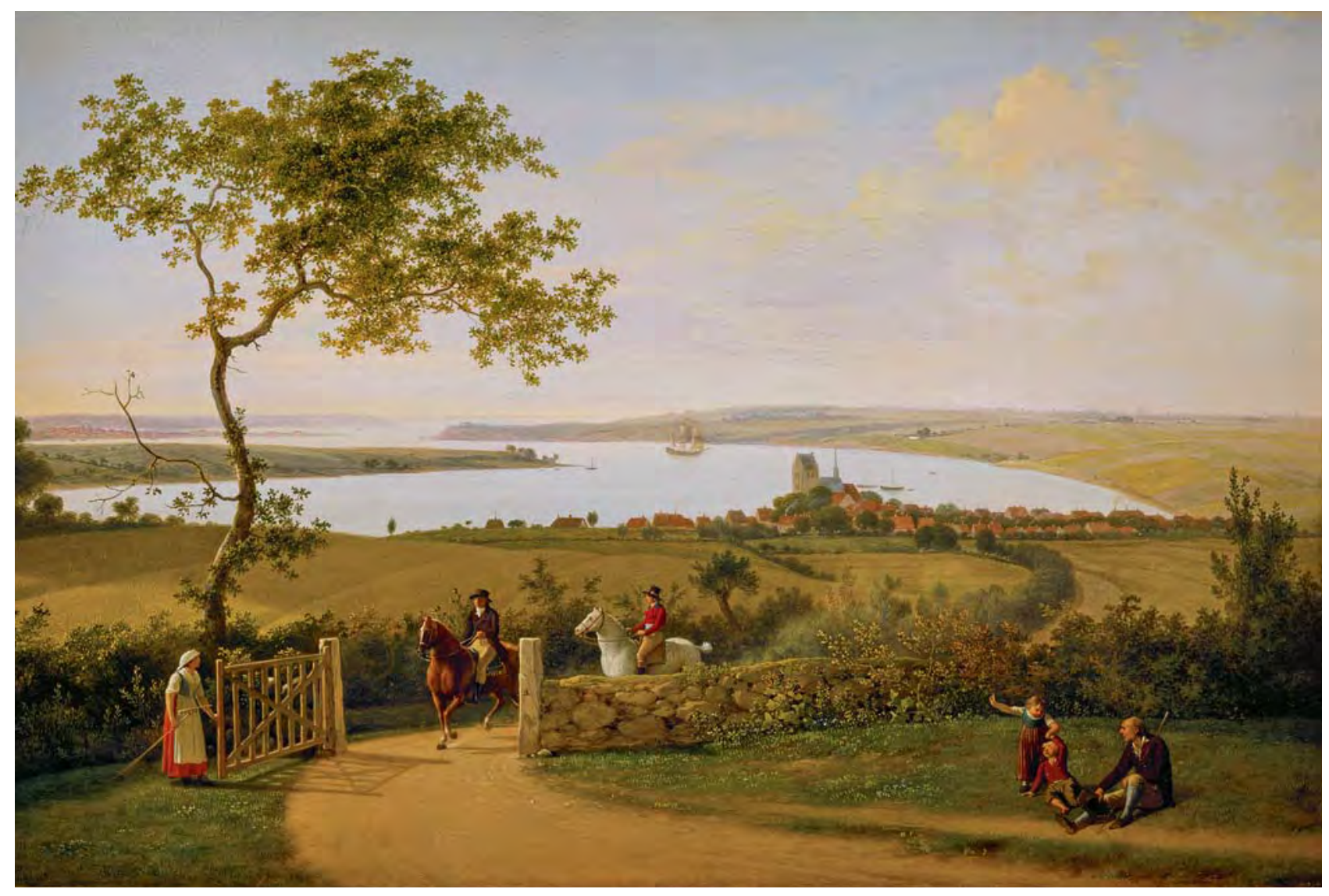

III. 4 [Jens Juel, View across the Little Belt from a hill at Middelfart, c. 1800.

Oil on canvas, $42.3 \times 62.5 \mathrm{~cm}$. Thorvaldsens Museum, Copenhagen, photo Hans Petersen]

seems deliberately to aspire to the natural, rather than the regulated. The winding road functions as a striking compositional element that unifies the picture planes rather than separating and instituting boundaries, as is the case in the former work. Class distinctions are emphasized in View across the Little Belt from Hindsgavl on Funen in a very distinct way from in View across the Little Belt from a bill at Middelfart. However, class difference is not abolished altogether in the second painting; instead, an easygoing co-existence of peasant and lord is implied. Patriotism and the great agrarian reforms were not only echoes of the 'Liberty, Equality, Fraternity' of the French Revolution, they were also a pragmatic means of maintaining the existing class boundaries by giving the peasants a number of concessions and new privileges.

\section{The Discovery of The Danish Landscape}

A common feature of the above-mentioned works by Juel is a discreetly elevated angle of vision that permits a wide view out over the landscape, thereby assigning a particular meaning to it. This mise-en-scène of his landscapes is hardly coinciden- 
tal. It was accentuated even more by artists later in the 19th century, culminating in Vilhelm Kyhn's (1819-1903) vast panoramas of the Danish landscape (Oelsner and Grand, Vilhelm Kyhn 155-183). But let us continue for the moment with this exploration of the early 19th century and its Romantic landscapes, which in this period begin to be profiled as an important artistic genre on an equal footing with history painting. However, new problems were brewing in these years. The enclosures and redistribution of farmlands, the abolition of adscription and the slightly later Forest Reserve Ordinance of 1805 , which left clear visual traces on the landscape, were all radical changes that led to an increased flow of people from countryside to town. The dissolution of the common agriculture of the village community in favour of more rational, parcelled-out farming meant, paradoxically, that the whole rural population could no longer be fed by agriculture. As a result, other occupations arose in the wake of increasing industrialization and the patriotic ideal of ensuring domestic production that was not luxurybased.

One of the visible results of this thinking was the establishment, on the English model, of a number of spinning schools all over the country which were to render superfluous imports of foreign luxury textiles; this is very probably the explanation for the linen bleaching in Juel's View from Sørup towards Fredensborg Castle. Another visible consequence of the reforms was the incipient metropoleformation of industrialization, which was of great importance for the increased popularity of landscape painting in this period. Greater population density in the towns meant that a large group of people lost their dependence on nature as a resource, and in the sheltering context of the town the modern urban human being could withdraw from nature, which could then be observed from this new position as 'landscape' (Ritter 24-50; Wamberg 9-23).

It is thus characteristic that landscape painting made its impact as an artistic genre in parallel with the emancipation of the urban citizen from a relationship of dependence on nature due to the changing conditions of production. And alongside these structural changes, there seems to have been a rationalization of the view of the landscape. It was now subjected to a succession of surveys and descriptions that would gradually encompass the whole Danish kingdom.

The reconfiguration of the villages and enclosures of the related lands required exact, accurate surveys of the countryside, and at the urging of the monarch the Royal Society of Sciences launched the first thorough survey of the kingdom of Denmark. This project was not concluded, however, until 1841, and in the interim it was taken over by the Office of the Ordnance Survey. But the surveying and description of the Danish kingdom was not only a matter for land surveyors, topographers, cartographers and geographers; literary descriptions of Denmark also made a significant contribution to this new interest in the Danish landscape.

In the Danish context, the most important literary work of the time was probably the historian and linguist Christian Molbech's (1783-1853) two-volume Ungdomsvandringer $i$ mit Fødeland, which appeared in 1811/1815. Molbech travelled all over Zealand, including Møn, as well as Funen and Jutland; the many other islands and parts of the country could not be treated within the confines of the 
work. Molbech's writings mediated the transition from a patriotic discourse to a National-Romantic discourse, in which issues of historical origins, nation and language emerged as new indicators of the individual's relationship with the nation. In this new paradigm, the nation could no longer be defined exclusively in terms of citizenship; instead, the concept of 'fatherland' became the decisive parameter for the individual's relationship to the state. As a crucially new feature, Molbech had an eye for the landscape he encountered on his journey around Denmark. He went beyond presenting the country's historic monuments to the reader; the natural landscape itself offered authentic experiences. Thus, in the work of Molbech, the landscape was understood for the first time as a constitutive element of the fatherland. In this perspective, Molbech's work became a veritable domestic guide to the Danish landscape (Damsholt 3).

The inspiration for Molbech's work was presumably as much the age's travel literature of 'sensibility', such as Laurence Sterne's (1713-1768) A Sentimental Journey through France and Italy (1768), as it was the contemporary topographical literature, for which Alexander von Humboldt's (1769-1859) Ansichten der Natur could be seen as an obvious model. But the exchanges with the pictorial art of the period were also an important source of inspiration for Molbech's writing. Ungdomsvandringer makes use of a number of visual, almost painterly descriptions throughout, which might indicate inspiration from the contemporary art of painting; the work itself must have had a similar galvanizing effect on the artists of the time. ${ }^{3}$

However, Ungdomsvandringer $i$ mit Fødeland cannot be regarded simply as a guide to the Danish national landscape. With its striking geographical choices and omissions, Molbech's work was also a picture of the transition from the United Monarchy of absolutism and patriotism to the nation state of National Romanticism. This was a process that was in motion in the rest of Europe too, not least as a result of the need to redefine nations as a result of the Napoleonic Wars.

Ungdomsvandringer $i$ mit Fødeland put words to a political and geographical process that was taking place concurrently. In 1814-1815, the Congress of Vienna helped to define the new Europe, in which the Duchy of Holstein was admitted to the German Confederation, while Norway was ceded. Denmark was no longer a Dual Monarchy but a monarchy with inherent territorial difficulties. In the longer term, this was not only a matter for the politicians and the military, but also for the artists of the time, many of whom were preoccupied with the national cause.

\section{The Call of the Fatherland}

What I have set myself as my life's purpose as a painter is to paint a beloved Denmark, but with all the simplicity and modesty that is characteristic of it; what beauty there is in these fine lines in our hills that undulate so gracefully that they seem to have emerged from the sea, in the mighty sea on whose shores the sheer yellow cliffs stand, in our woodlands, fields and heaths. But only a Dane can paint it; how false is often the tone of the pictures 
that German landscape artists paint here; it can be so offensive that I often become unfair and overlook the beauties in them. Then of a full heart I wish that I might once depict the natural beauties of my native land such that it may be obvious to anyone that they are so greatly mistaken. (Lundbye 49)

An early major National-Romantic work is J. Th. Lundbye's and P. C. Skovgaard's joint decoration of the hall in the stockbroker H. C. Aggersborg's (1812-1895) apartment on the occasion of the latter's marriage to Dorothea Elisabeth Bræmer (1810-1879). However, this has been somewhat neglected in critical accounts. The wedding took place on 8 th June 1842 , and as a setting for the subsequent domestic festivities Aggersborg had commissioned a threefold decoration showing Højerup Church at Stevns Klint (painted by Skovgaard), the Goose Tower in Vordingborg (painted by J. Th. Lundbye after a sketch by Skovgaard) and Frederiksborg Castle (painted by Skovgaard; ills. 5-7).

Aggersborg, who was Skovgaard's uncle and the half-brother of his mother, belonged economically and socially to the country's powerful elite, a group whose demand for landscape paintings was growing all the time. Seen in this light, it is obvious why Aggersborg wanted an artwork for his home in central Copenhagen that embraced the trinity of landscape, people and history. From the sheltering context of the city, the wedding was evidently to be celebrated amongst depictions of natural landscapes that inspired love of one's country.

In Lundbye's diaries we can follow the genesis of the three works. The commission was finally issued in April 1842; Skovgaard and Lundbye only had a few months to get the trilogy finished and installed in the apartment. In his diary entry for 18 April 1842, Lundbye writes:

Today I have begun work on the painting I am to paint for Skovgaard's uncle, showing the Goose Tower at Vordingborg, after a drawing by Skovgaard; I am looking forward to this work, which can be dealt with lightly and broadly; it will be good practice for me, for my own large work from Jægerspris. (Lundbye 6o)

And a few days later:

However, I must also remember this day, when I painted the Goose Tower; I have rarely felt such pleasure over any of my works as over this; it is as if I had been there, as if I knew it well, and yet I have never seen it. I can truly feel how beneficial it is for me to paint this piece. - I will go up on the city ramparts now to hear the many bells of the city ringing, will mix in with the crowd and be glad, as one is permitted to be when one has spent one's day well. Today Orla Lehmann got out of his prison again. (Lundbye 63)

And finally, on 2 June, Lundbye writes that the work has been completed:

Now the hall is finished at Skovgaard's uncle's; for three days Skovgaard and I have worked strenuously down there, but how well it has succeeded I do not know. I will not answer for more than the things I have painted, which will be hard enough to defend for a strict judge 
like Høyen. As a whole, I have no opinion of it; I do think, though, that there is life and delight in the treatment - now we shall get to hear what people will say'. (Lundbye 75)

Skovgaard himself only mentions the work in passing in his preserved correspondence. Fortunately, we have Lundbye's description of the process behind the decoration job; he also lifts a corner of the veil covering the conceptual history of the trilogy. The National-Liberal politician Orla Lehmann (1810-1870) had just been released from his imprisonment for giving his so-called 'Falster speech' in Nykøbing Falster in 1841, when he agitated for the support of the farmers in the National-Liberals' struggle for a free, democratic constitution. Lundbye also mentions the art historian N. L. Høyen (1798-1870), with whom not only Lundbye, but also the majority of the other Danish artists of the time were closely associated.

Høyen held a number of posts as an art critic and teacher at the Royal Academy of Fine Arts and later also at the university, not the least of which was his influential position as chief curator of the Royal Art Collection with the archaeologist Christian Jürgensen Thomsen (1788-1865). Høyen was deeply committed to the national current which, prepared by the patriotic reforms and the dawning love of one's country, was being borne up by the National-Liberal movement. ${ }^{4}$ Høyen was active in the Scandinavian Society, founded in 1843, under whose auspices several of his epoch-making lectures were held. ${ }^{5}$ In 1847 , he founded the Society for Nordic Art, and he was directly involved in its concrete political work.

Concerning the last of these, the Professor of Botany and Skovgaard's future father-in-law, J. F. Schouw (1789-1852), wrote to C. P. Neergaard (1793-1860), the tenant of the Vognserup estate:

You have done me the honour of asking me to recommend a man who could stand as an electoral candidate for the Rigsdag in the second district of Holbæk County. I believe I could respond to this request no better than by proposing to you our mutual friend, Professor Høyen. You know yourself of his high principles, his unusual independence and his warm love of his country. You know that he has a very wide knowledge of many things and that, although he has not yet made affairs of state the object of his studies, through his historical research he is aware of much in that respect; - to this we can add his rare eloquence, and what in a rural electoral district must surely also be considered, his warm feelings for the farming class, from which he himself originates. ${ }^{6}$

Aggersborg's wedding decoration was thus not only to be judged by the most influential art historian of the time; it was also to be assessed by a man with strong National-Liberal convictions. Notwithstanding the private nature of the decoration, it was always going to be inspected by Høyen. The Aggersborg home housed a large art collection which was open to like-minded people.? Lundbye does not write about Høyen's reception of the works, and no other sources tell us anything about it. But if we consider the pictures themselves, it does not seem too hasty to conclude that they were probably well received. Their subjects include: a medieval church situated by the mighty cliff Stevns Klint to which many popular legends 


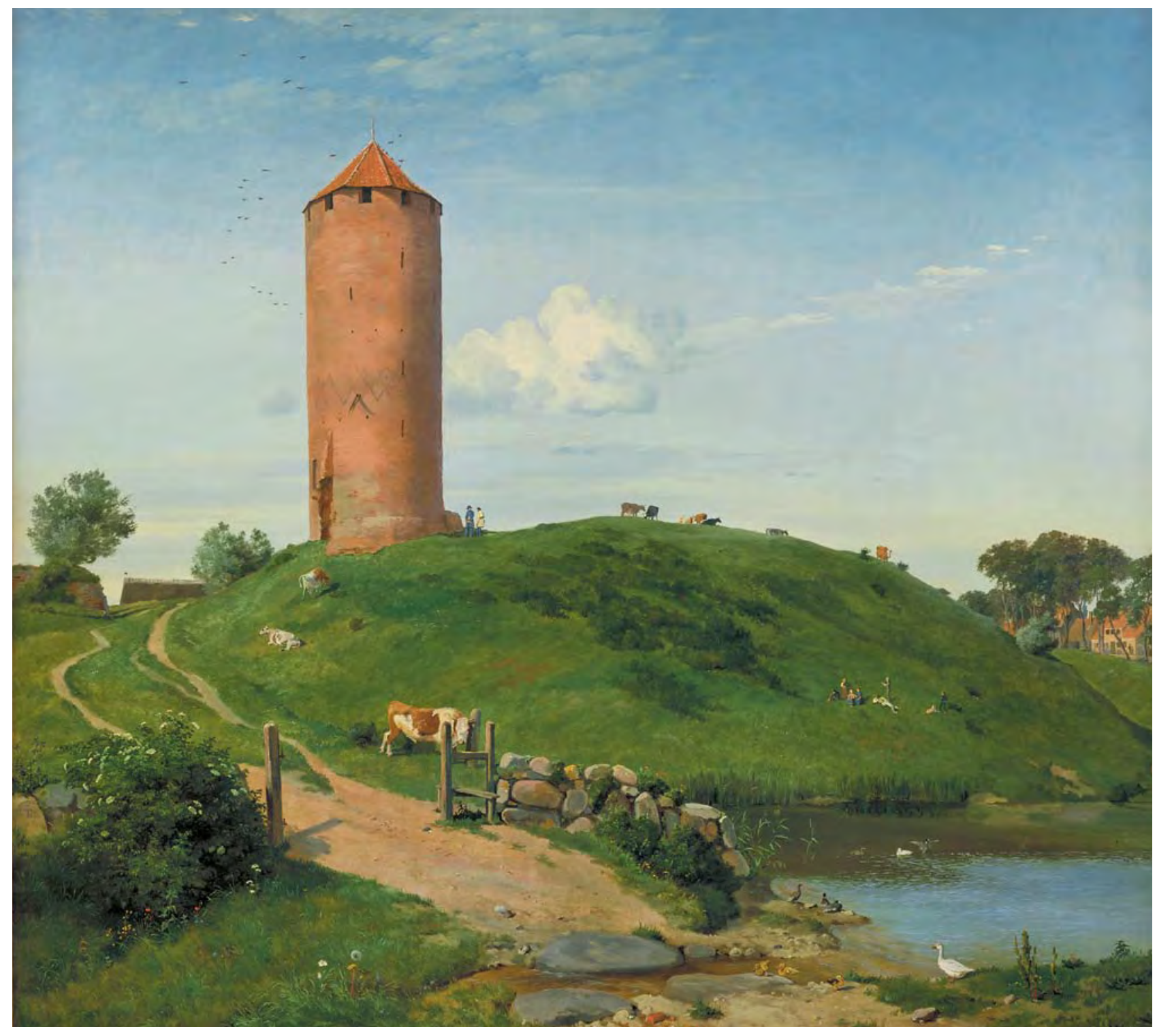

III. 5 [J. Th. Lundbye, The Goose Tower in Vordingborg, 1842.

Oil on canvas, $141.2 \times 156.5 \mathrm{~cm}$. Statens Museum for Kunst, Copenhagen, photo SMK Foto]

were attached; a medieval tower from the fortifications of King Valdemar Atterdag in Vordingborg; and a Renaissance castle in northern Zealand. All are situated in the Danish landscape.

These works were not just artistic responses to the new culture-bearing bourgeoisie's call for landscape painting; to a great extent they were also a political response to the burgeoning National Romanticism of the time. This movement was associated with the notion of 'the fatherland', a concept that was geographically demarcated as the nation state of the 'Denmark to the Eider' policy, as it was pointedly formulated by Orla Lehmann in 1842:

Our Denmark is thus the realms and lands of the King of Denmark, less Holstein, but including Schleswig. That this will gain the free approval of the Schleswigers I feel certain, if only the distinctive conditions and administrative independence of Schleswig are 
respected, and as long as we can bring it about that it means freedom and happiness to be a part of Denmark. My toast is therefore to the freedom and happiness of Denmark 'Denmark to the Eider'. Long live Denmark! (Lehmann 1842)

On the whole, the trilogy involves a number of motifs which had been canonized by Christian Molbech as particularly and significantly Danish. ${ }^{8}$ The middle work was of the Goose Tower, which had quickly been established as a tourist destination, as is evident from Politievennen in 1828: 'If there were a bench or some chairs, and a telescope could be obtained as well as the key to the tower, it would certainly please many people, and with pleasure they would pay more for admission to such a beautiful view.'

The Goose Tower is the only preserved tower from King Valdemar Atterdag's defences against the Hanseatic cities to the south. ${ }^{9}$ As such, it constituted a historical parallel to the conflicts of the time with the German duchies, which must presumably have played a role in the popularization of the motif through the 19th century. ${ }^{10}$ Lundbye has placed the tower in classic Danish natural scenery. In his painting, it crowns the top of a small hill; a little winding road leads up to it, and on the hill between this and a grazing herd of typical Danish red-and-white dairy cows a group of children are resting while ducks and geese grub in the little pond. The winding course of the road builds a bridge between nature and culture, making the resting children representatives of the rebirth of the proud past that formed an important part of the age's idea of historical continuity, in which the past becomes mirror for the present. As Høyen formulated it: 'A greater, more meaningful battleground opens up for him, where it is not only a matter of developing talent and having it appreciated, but where he also struggles for his native land, for all of Nordic nature, for the life of the people and all the great memories of the past.' (Ussing 359).

To the left of the picture of the Goose Tower hung Skovgaard's Højerup Church at Stevns Klint. Despite the title's emphasis on the church, it is almost hidden behind tall trees in the painting. Instead the artist's focus is on the vast cliff, Stevns Klint, which in one long undulating motion exposes 65 million years of history and prehistory sedimented in its horizontal geological strata. This is a very different historical span from the one in the preceding picture. Measured against this grand narrative of Denmark's creation and genesis, both the church and the fishermen on the beach seem to hold a subordinate position. It is no wonder geology as a discipline was particularly successful in this period, with Johan Georg Forchhammer (1794-1865) as its most prominent figure.

The last part of the trilogy is Skovgaard's View from Frederiksborg Castle, in which we view the subject from yet another angle - this time there is a kind of bird's-eye perspective, such that we have a wide view out across the surroundings of the castle with the lake and the Danish beech wood in the background. Frederiksborg Castle had already been described by Molbech, who like Skovgaard emphasized the view offered by the castle as an essential characteristic of what was held to be one of northern Europe's most beautiful Renaissance castles. Molbech writes: 


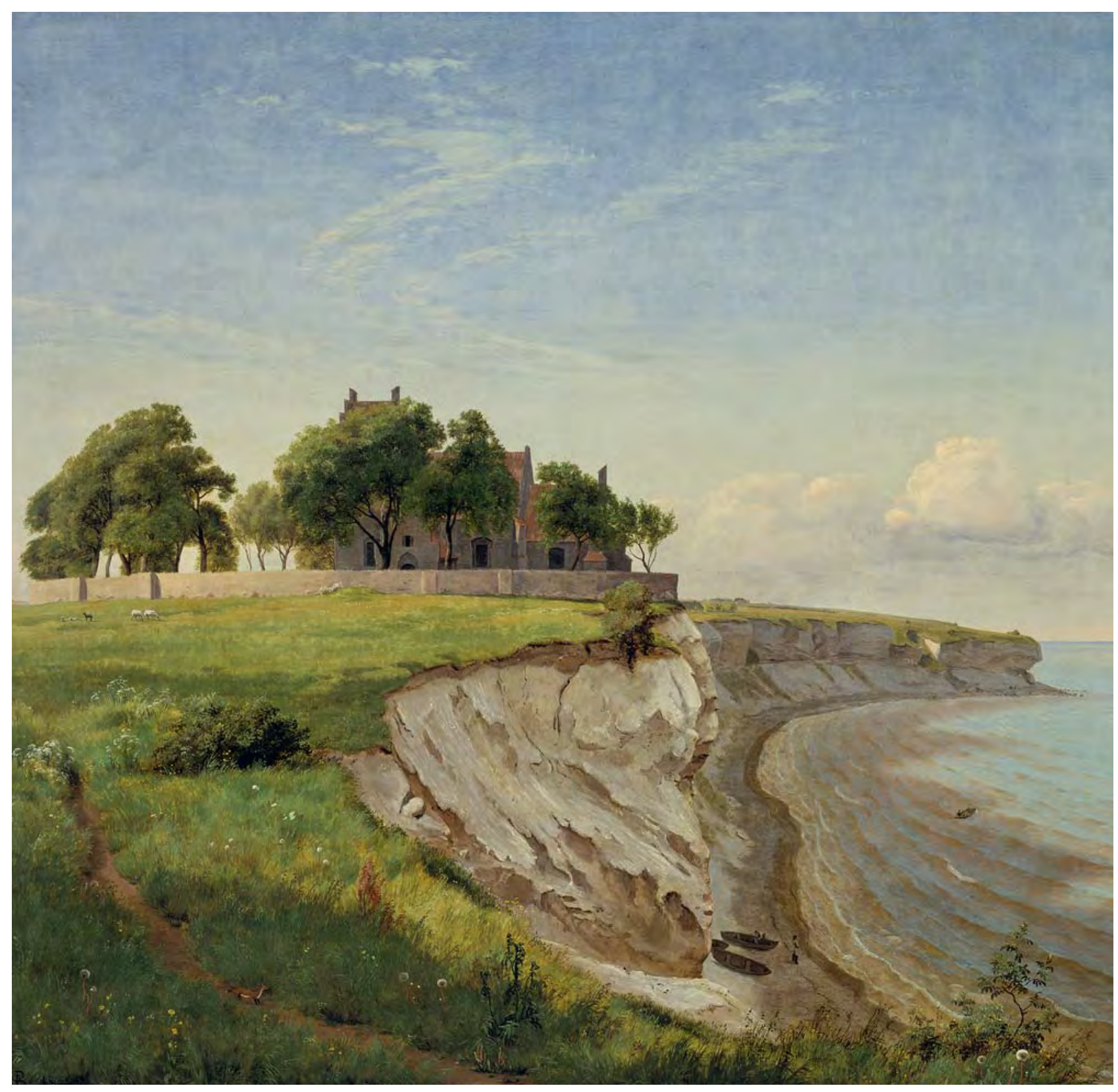

III. 6 [P. C. Skovgaard, Højerup Church at Stevns Klint, 1842.

Oil on canvas, $142.2 \times 149.5 \mathrm{~cm}$. Statens Museum for Kunst, Copenhagen, photo SMK Foto] 


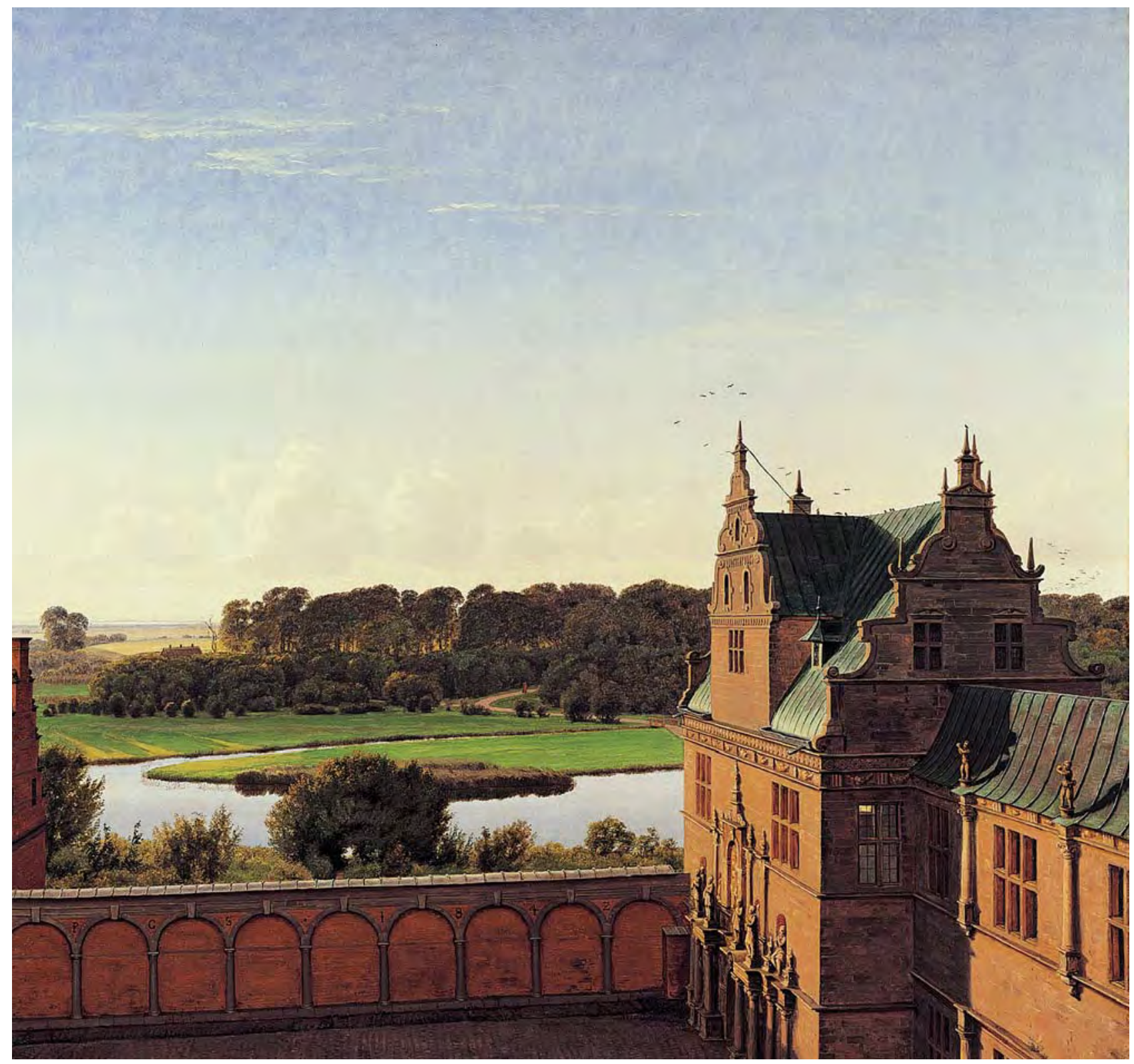

III. 7 [P. C. Skovgaard, View from Frederiksborg Castle, 1842.

Oil on canvas, $140 \times 150 \mathrm{~cm}$. Ordrupgaard, Copenhagen, photo Pernille Klemp]

I was lured to the windows and the wonderful, lovely view across the lake [...]. Especially yesterday with the afternoon sun and the clear spring sky, it was so entirely charming that more than once I had to confess that the view is one of the finest things the castle possesses. (Molbech 10-11)

As a whole, the trilogy is a clear example of the politically motivated contemporary art which, with inspiration from Johann Gottfried Herder, subscribed to the idea of an identity of nation, culture, people and history. The trilogy should therefore be seen as a major work of National Romanticism with its celebration of the Danish landscape, monuments and people; its structure shows a forward-thrusting, almost evolutionary progress from morning (Højerup Church) through noon (the Goose Tower) to evening (Frederiksborg Castle), but it is also 
a statement about a process that flows from God (Højerup Church) through King (Valdemar Atterdag's Goose Tower) to Fatherland (the view of nature at Frederiksborg Castle). It should be noted that the monuments chosen and their surrounding landscapes were not representative of Denmark as a whole; they are all in Zealand. The Goose Tower is in southern Zealand, Stevns Klint in central Zealand, and Frederiksborg Castle in northern Zealand; all together they give us a picture of the Zealand that was the National-Liberal citadel. Jutland was only just beginning to become established as a subject for the art of the Golden Age, a point that will be dealt with later.

\section{National-Liberal Commissions}

The political signals in the Aggersborg decoration were unmistakable, and in subsequent years Skovgaard and Lundbye both received a number of commissions from National-Liberal politicians. Among the most prominent patrons in the National-Liberal group was Orla Lehmann, who built up a substantial art collection over the years (Damsgaard 91-118). In 1844, Lehmann married Maria Puggaard (1821-1849) and thus became a member of a particularly prosperous, politically engaged and art-loving family. We find works by, among others, Skovgaard, Constantin Hansen, Lundbye and Kyhn in Lehmann's collections. Lehmann's collection of Lundbye's works included Bleaching ground at the manor of Vognserup from 1844-1845, which is closely related to a work in Randers Kunstmuseum (ill. 8).

As noted earlier, the tenant of the Vognserup manor was a National-Liberal sympathizer called Neergaard. In a way the dialogue with Juel's previously-mentioned work is obvious. Here too cotton lies bleaching, ${ }^{11}$ yet Lundbye's work is otherwise very different. The landscape is no longer seen from an elevated vantage point; we are situated as viewers on a normal plane in relation to the subject, and this brings us face to face with it. Here, a single red dairy cow grazes in the fertile landscape, and a single woman is the only human presence. For Lundbye the busy work of the peasants is no longer a guarantee of the patriotic society with its emphasis on citizens' actions for the benefit of their country. Instead the conjunction of the bleaching cotton, the peasant woman, the dairy cow in the grass and the lush green surroundings shows that nature and mankind's utilization of it is no longer able to ensure the economic foundation of the state, but that the farmers must be considered living representatives of Denmark's glorious past. Along with the exuberant depiction of nature, they are the source of the budding national movement and its hopes for a free constitution - just as in the farming society of prehistory. Lundbye himself said of the work on the large painting, which grew up against the background of a sketch:

This picture was meant to show the fertility and peace that can be in such a small view, just outside a manor house garden; it was not the magnificence in nature that I wanted to paint - one senses the hand of man much more everywhere - but the opulence that permits the ground to be seen nowhere for grass and plants.' (Henschen et al. 77) 


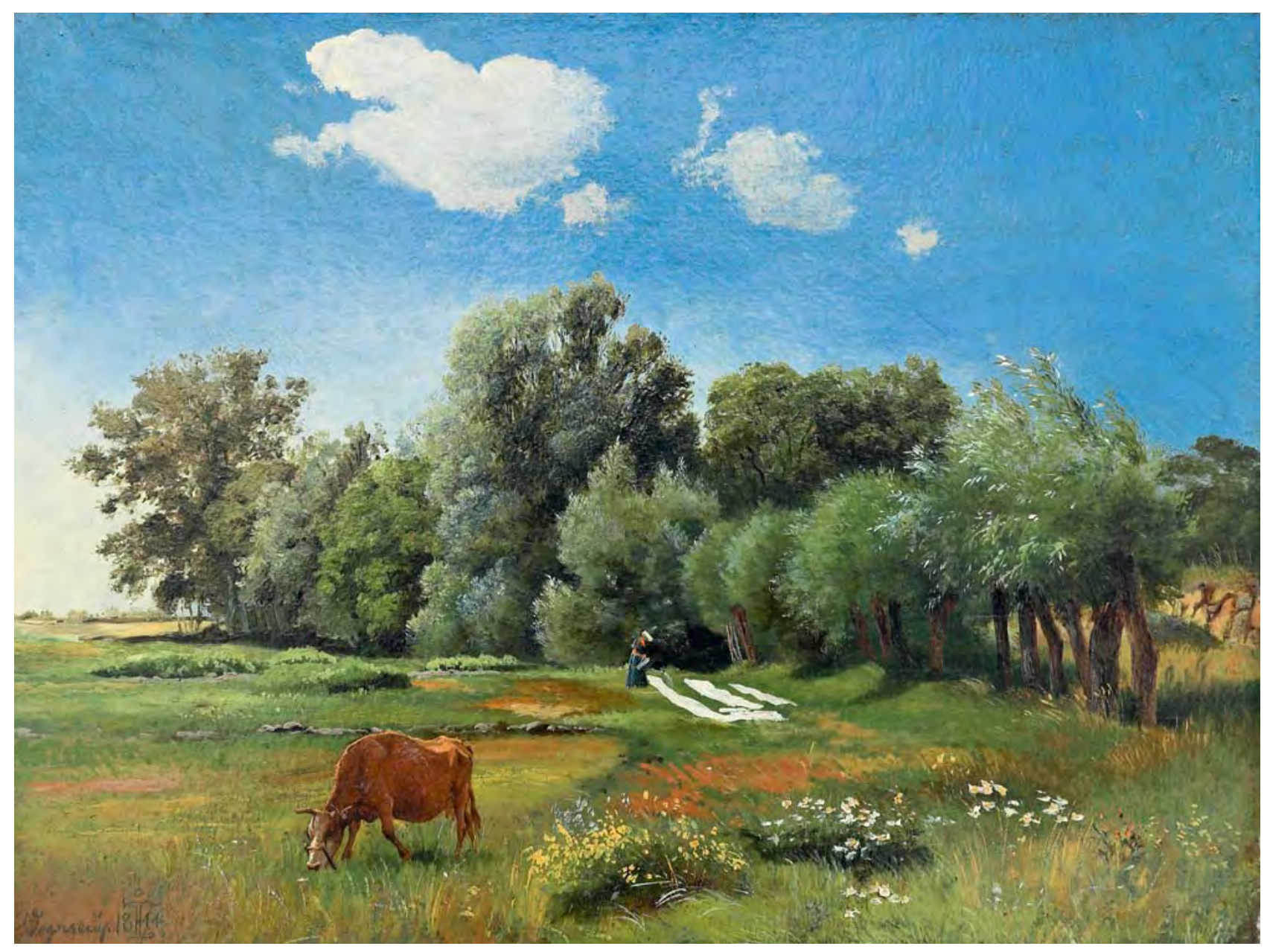

III. 8 [J. Th. Lundbye, Bleaching ground at Vognserup, 1844-1845.

Oil on canvas, 31.5 × $42 \mathrm{~cm}$. Randers Kunstmuseum, photo Niels Erik Høybye]

Lehmann's interest in pictorial art can be documented by the many works he commissioned, and to some extent by the preserved correspondence. In particular, Lehmann associated himself closely with Constantin Hansen; using the evidence of major commissions and letters we can observe how he makes specific recommendations and commissions to exploit the potential of art to advocate the fundamental National-Liberal ideas. This comes to expression most significantly in the large decoration for the vestibule of the University, which Constantin Hansen executed with Lehmann on the sideline. For this, Lehmann not only sent Constantin Hansen a detailed program; he also provided him with the historical-philosophical key to the decoration program Lehmann wanted him to realize. After receiving the long, detailed proposal for the decoration program, Constantin Hansen wrote to Lehmann: 'Hegel's Philosophie der Geschicte has interested me greatly, and I thank you many times for the gift' (Glarbo 35). The 
philosophy of Georg Wilhelm Friedrich Hegel was of enormous influence among the National-Liberal thinkers of the age, ${ }^{12}$ most of them presumably read the work in the original language, but in 1842 the first Danish translation of Hegel's influential work also appeared.

If Hegel's philosophy had such a strong impact in the period, it was probably because it supplied the philosophical arguments for the constitutional ideals for which the National-Liberals and a number of artists on their side were struggling. For example, Hegel championed bourgeois democratic rights along with the maintenance of the state, and the introduction of a democratic form of government against the background of a constitutional monarchy is based on the idea of evolutionary progress. From time to time Constantin Hansen was to envy the other artists, especially the landscape painters, who 'had a far easier time covering a piece of canvas with colors than the figure painters, which they are of course far too wise to admit. ${ }^{13}$

However, if we look more closely at a couple of Skovgaard's works commissioned by Lehmann and the related correspondence, the matter appears less simple than this. In 1846, Skovgaard received a commission for the work Summer day (ill. 9). On the occasion of its completion Lehmann wrote to Skovgaard: 'Dear friend! I suspect my piece has cost you more effort than you expected when we spoke of the price. So I ask you to inform me of this, regardless of earlier agreements and statements' (Lehmann, letter to P. C. Skovgaard). Despite the friendly enquiry, though, Skovgaard refused to accept extra payment for the work. We can only guess at the reason for this. One possibility is that he had no wish to prejudice future possible commissions: especially, it seems, when the reception of the work was so very positive. At least Lehmann wrote: 'After your letter came yesterday, I have no choice but to obey. It must naturally please us both that all the world agrees with us that it is a charming picture.'

Summer Day is a convincing translation of the National-Liberal ideology into a pictorial idiom. Skovgaard gives us the essence of the Danish landscape: beneath the blue sky of summer with domed cumulus clouds, ${ }^{14}$ a group of women and children are resting among the kerbstones in the shelter of an ancient mound covered in vegetation, ${ }^{15}$ while the men are at work in the far background of the picture. The whole scene is framed by full-crowned leafy trees, probably beeches, which were starting to be seen as the Danish national tree. The proud past of the country was to be reinvigorated among the farming class, who were considered the living heirs of the free yeomen of yore. Perhaps the stone circle demarcates more than the ancient barrow; it is tempting to assume that this could have been a kind of 'thing-stead', the proto-democratic assembly site of prehistory. The work thus perfectly exemplified the strengthening of the national painting that Lehmann was advocating in 1846, along with the idea of creating a Danish national gallery (Frandsen 120). ${ }^{16}$

Lehmann must have been particularly satisfied with the work, for shortly after the end of the First Schleswig War Skovgaard again received a commission from him; and the result was View of Vejle, 1852 (ill. 10). Orla Lehmann's generally controversial political activities, and his actions on the occasion of the so-called 


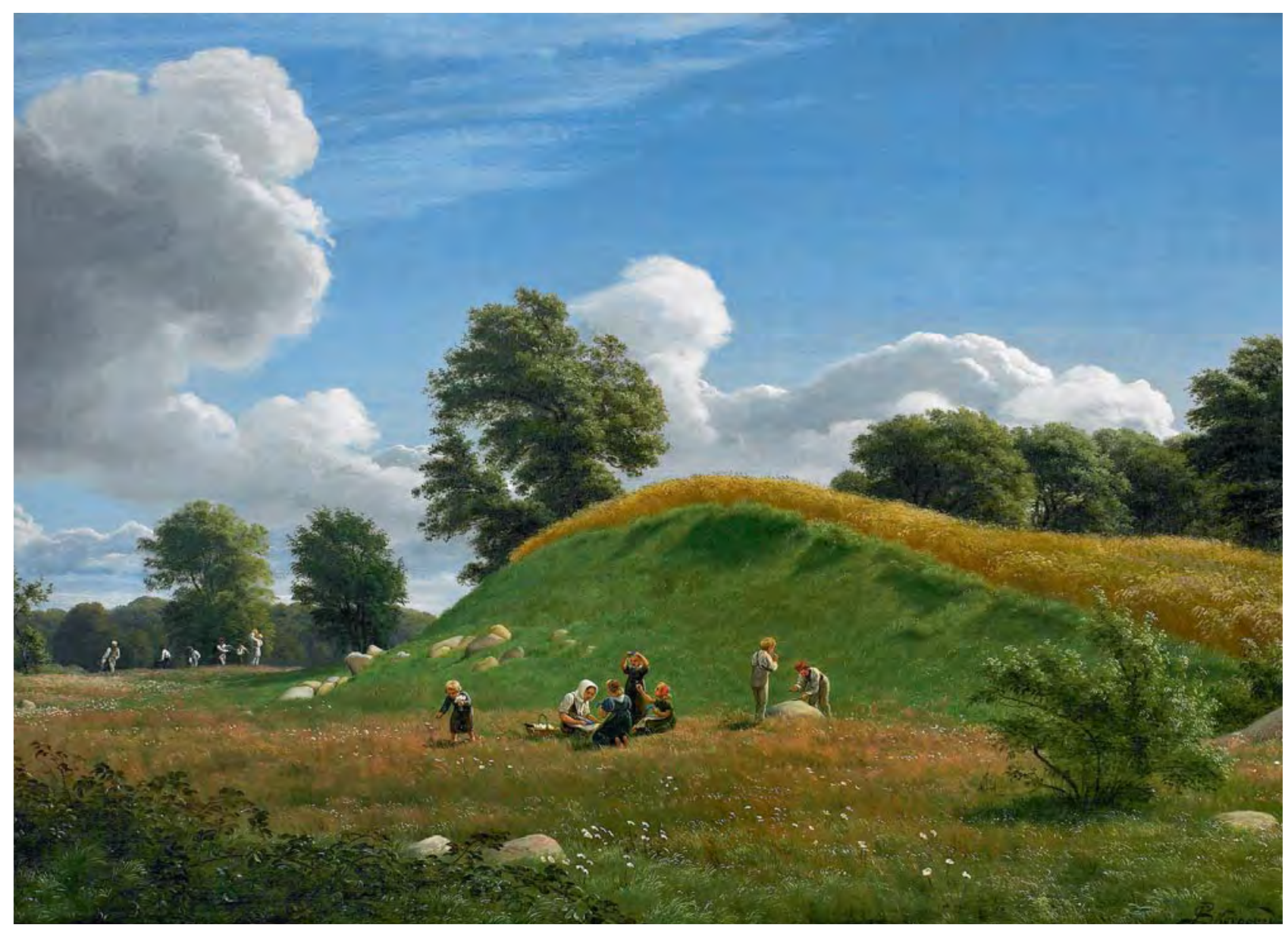

III. 9 [P. C. Skovgaard, Summer Day, 1846.

Oil on canvas, 65.5 x $93.5 \mathrm{~cm}$. Horsens Kunstmuseum, photo Svend Pedersen]

Casino Meeting of 20 March 1848 - at which Skovgaard, with his National-Liberal sympathies, as well as Jørgen Sonne (1801-1890 ${ }^{17}$ and Constantin Hansen all participated as representatives of the artists - meant that in 1849 he was appointed county prefect in Vejle in Jutland. An appointment in Holbæk on Zealand would also have been an obvious possibility (Wammen 126); Lehmann's new position took him much further from the centre of power.

At this time, Jutland was a relatively new subject for visual art, though the literati, topographers and geographers had long been extending their exploration and 'repatriation' of Jutland, which for centuries had played second fiddle to the culture-bearing elite which defined itself and Denmark from the vantage point of the capital (Frandsen 78-109). Viewed from this perspective, one may well speak of a personal exclusion, but on the other hand it was politically quite in keeping with the rediscovery of Jutland which intensified from the ceding of Norway in 1814 until the secession of the duchies in 1864, as a result of a diminished Denmark's search for a new national identity. 


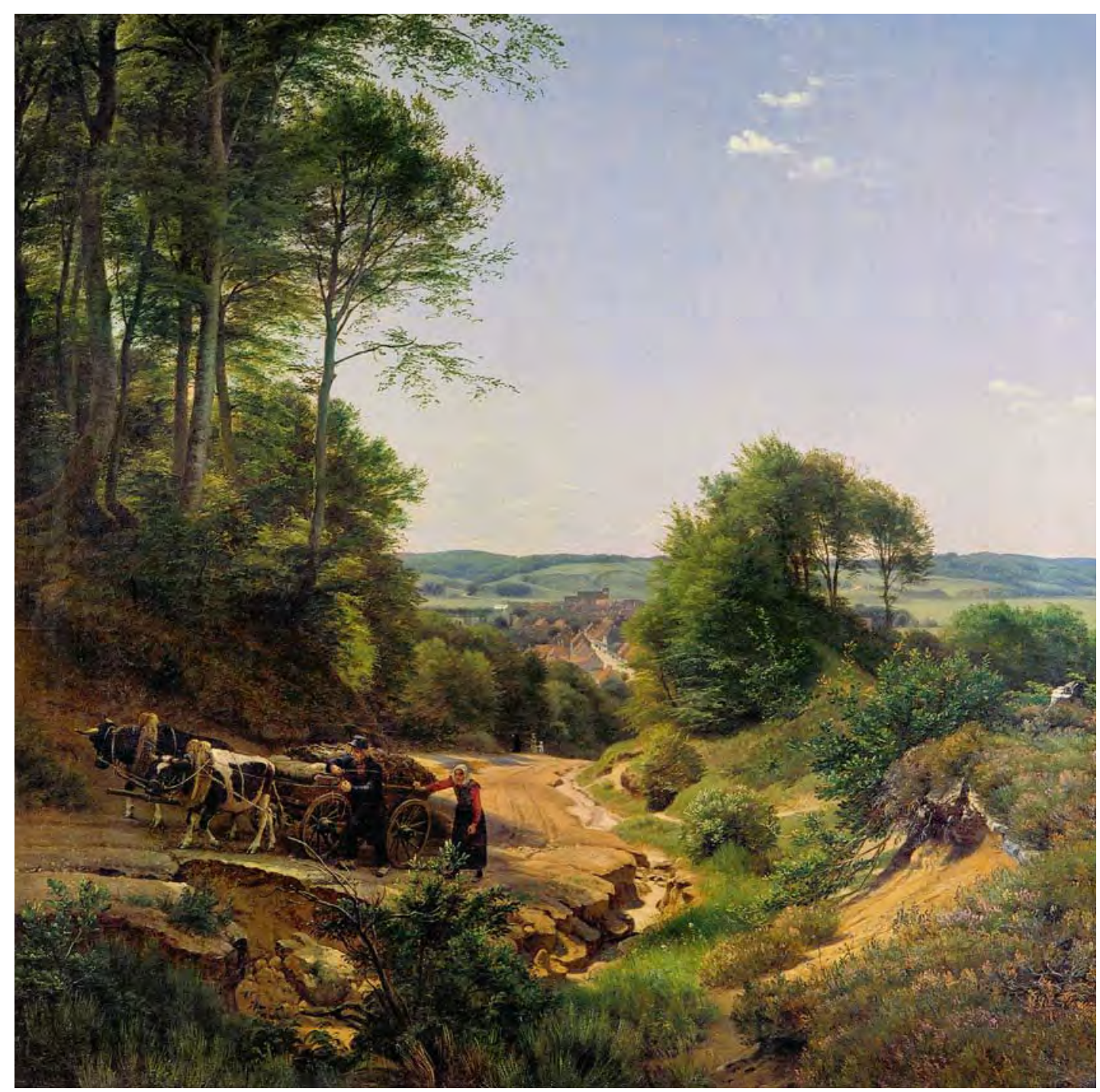

III. 10 [P. C. Skovgaard, View of Vejle, 1852.

Oil on canvas, $98 \times 100 \mathrm{~cm}$. Vejle Kunstmuseum, photo Keld Jensen]

Skovgaard's response to this was a picture that included features associated with the beech woods favoured by the Zealand aesthetic, but at the same time differentiated itself by its emphasis on the hilly terrain which had no parallel in Zealand. The hilly landscape is viewed from a high point, with the town of Vejle in the embrace of the valley far off in the distance. The picture is built up around a winding gravel road which is lined with slender beeches, and on the road there is a scene of an ox-drawn cart toiling uphill with the aid of a couple belonging to the farming class. Far down the road, a group of bourgeois ladies and children are moving in the same direction. Since the Falster speech of 1741, Lehmann had struggled persistently to mobilize the farming class in the battle against absolutism, and after the adoption of the June Constitution to convince the 'Friends of the Farmers' that the National-Liberals were an obvious political ally (Wammen 224-226). Perhaps it was these factors that Skovgaard, with Lehmann as his commissioner, was referring to in his interpretation of the Vejle landscape? It is at all events worth noting that neither of the figure groups on the road is present in 


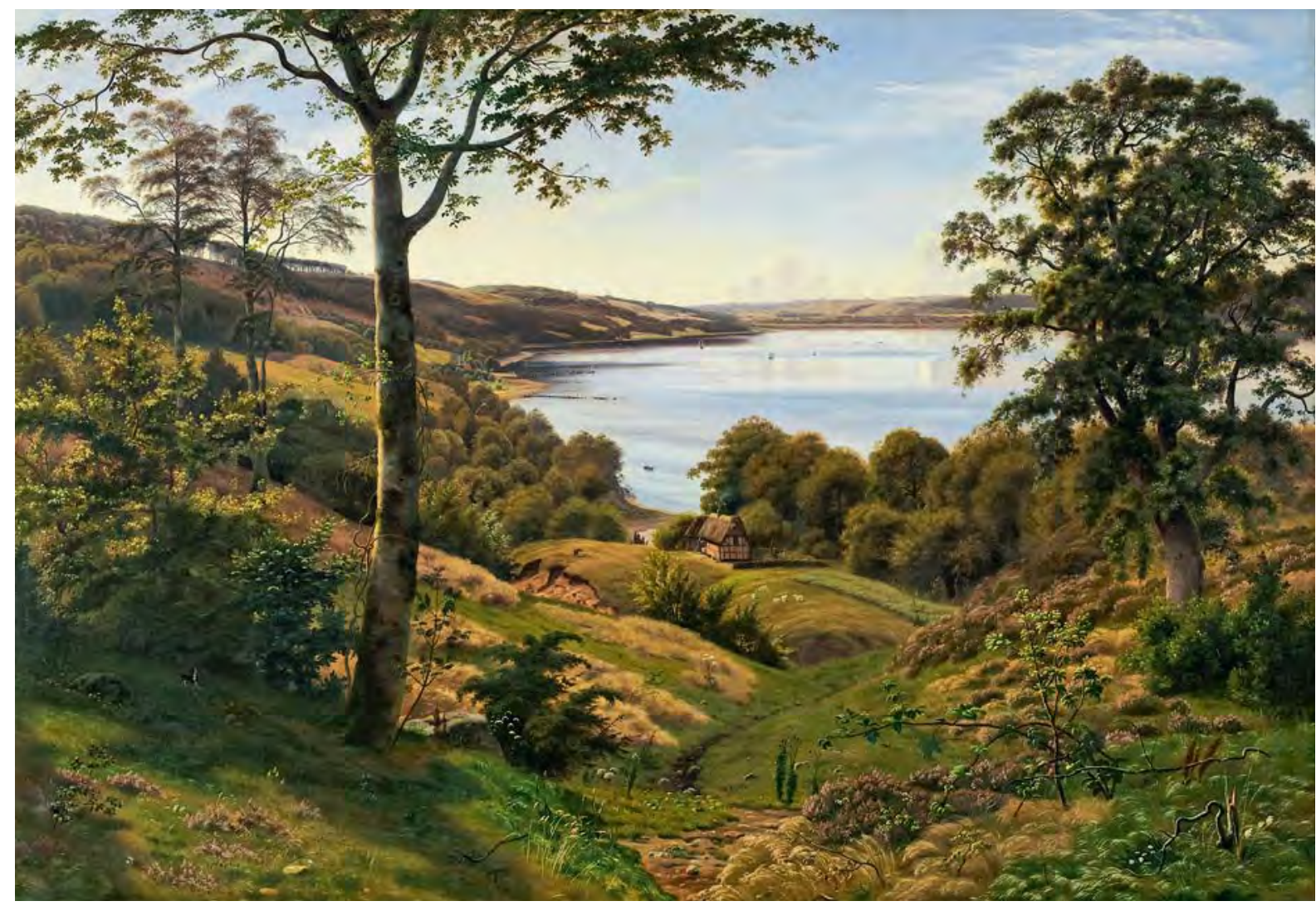

III. 11 [Vilhelm Kyhn, View by Vejle Fjord, 1862.

Oil on canvas, 151 x $221 \mathrm{~cm}$. ARoS Aarhus Kunstmuseum, photo Ole Hein Pedersen]

the preliminary sketch for the work; nor are the tall, slender beeches as prominent as in the final work. These are features which may reasonably be assumed to have entered the picture at the wish of the commissioner in order to accentuate the national statement in the piece.

A decade after Skovgaard's View of Vejle, Lehmann received a major work by another artist, Vilhelm Kyhn. The imposing View by Vejle Fjord (1862; ill. 11) helped to consolidate the place of Jutland in the narrative of the nation state Denmark (Oelsner and Grand, Vilhelm Kyhn).

In 1862, Lehmann had joined the Government again, which was now headed by C. C. Hall (1812-1888), meaning that he no longer lived at the county prefecture in Vejle. Nevertheless, Vejle was still a sought-after artistic subject, perhaps because it remained important for the centre of power in Copenhagen to have knowledge of the part of the kingdom that lay outside the narrow geographical confines of northern Zealand. Kyhn's depiction of the magnificent landscape around Vejle was based on accurate, detailed nature studies made on the spot during previous stays. However, the finished work testifies to the National-Liberal conception of Denmark as a unified country. As Orla Lehmann put it in 1838, 'There are no provinces in Denmark.' And despite the starting point of the work 


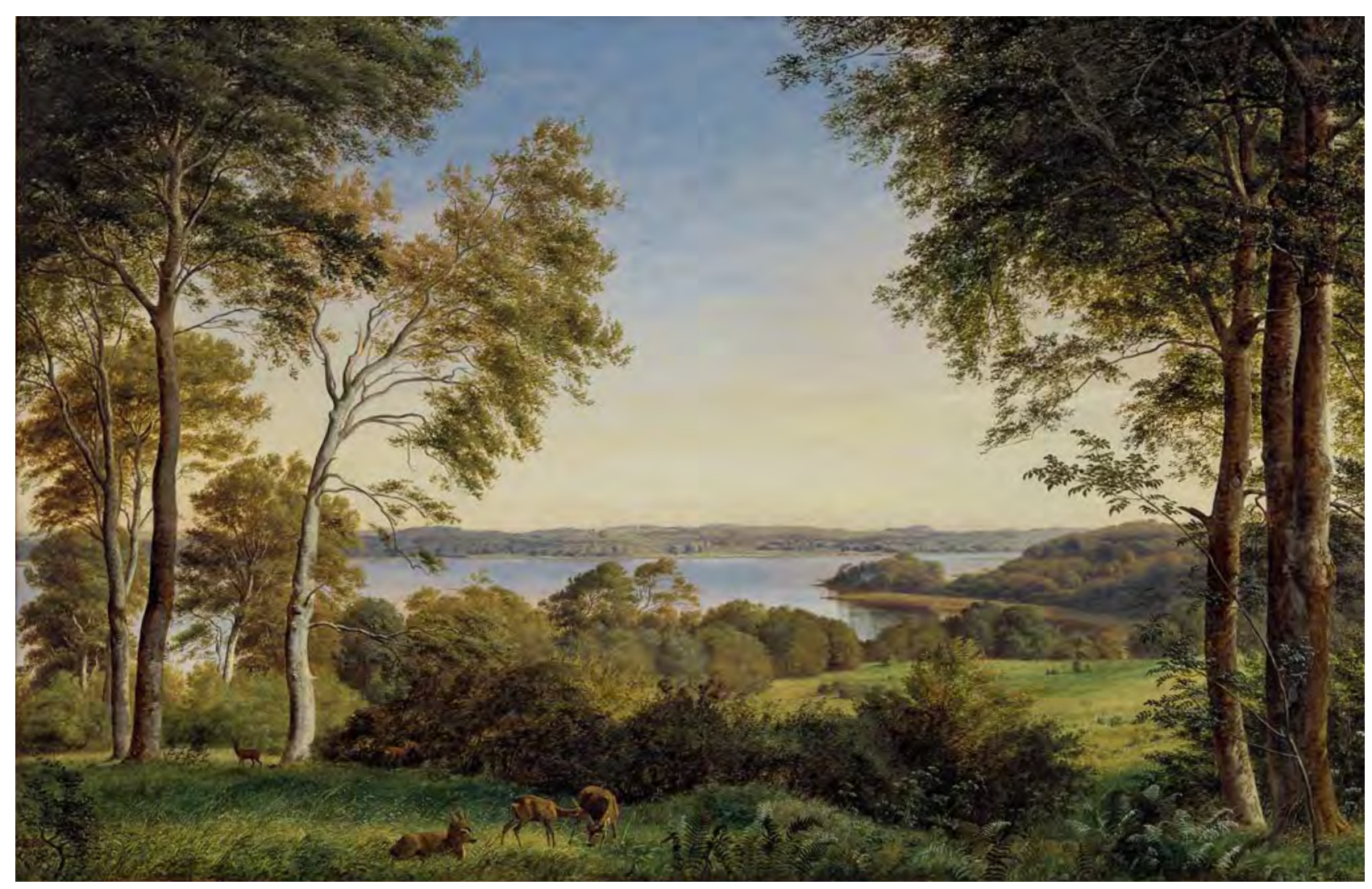

III. 12 [P. C. Skovgaard, View of Lake Skarre, 1845.

Oil on canvas, $127 \times 195 \mathrm{~cm}$. Statens Museum for Kunst, Copenhagen, photo SMK Foto]

being so specific to the place, it is also striking to see how much the subject recalls, for example, P. C. Skovgaard's monumental subject from the lake Skarresø (View of Lake Skarre, 1845; ill. 12). It was not far from Zealand to Jutland.

Lehmann was not alone either in his interest in art or his Hegel-inspired political ideology. We recognize both characteristics in the work of the theologian and politician D. G. Monrad (1811-1887), who over the years built up a similarly large collection of art by a number of the same artists (Jacobsen). Both Skovgaard and Constantin Hansen, to name but two, were represented in his collection. Among the works by Skovgaard was a picture from Møns Klint: 'When the exhibition is over, we shall have two pieces by Skovgaard, the one rejected in Norway, which is thus not the same one that Elisa Stampe was enthusiastic about, and a "Møns Klint". I am well pleased with both. ${ }^{18}$ In the book about Monrad and his art collection, it is suggested that the 'Møns Klint' picture in question is identical to Fuglsang Kunstmuseum's View of Møns Klint, c. 1846 (ill. 13; Jacobsen 68), where the dimensions of the cliff and the stratified geological sedimentation are marked despite the modest size of the work. This feature is exaggerated by the two human figures and the dog placed at the vanishing-point of the picture.

Subjects from Møns Klint preoccupied Skovgaard for several years from 


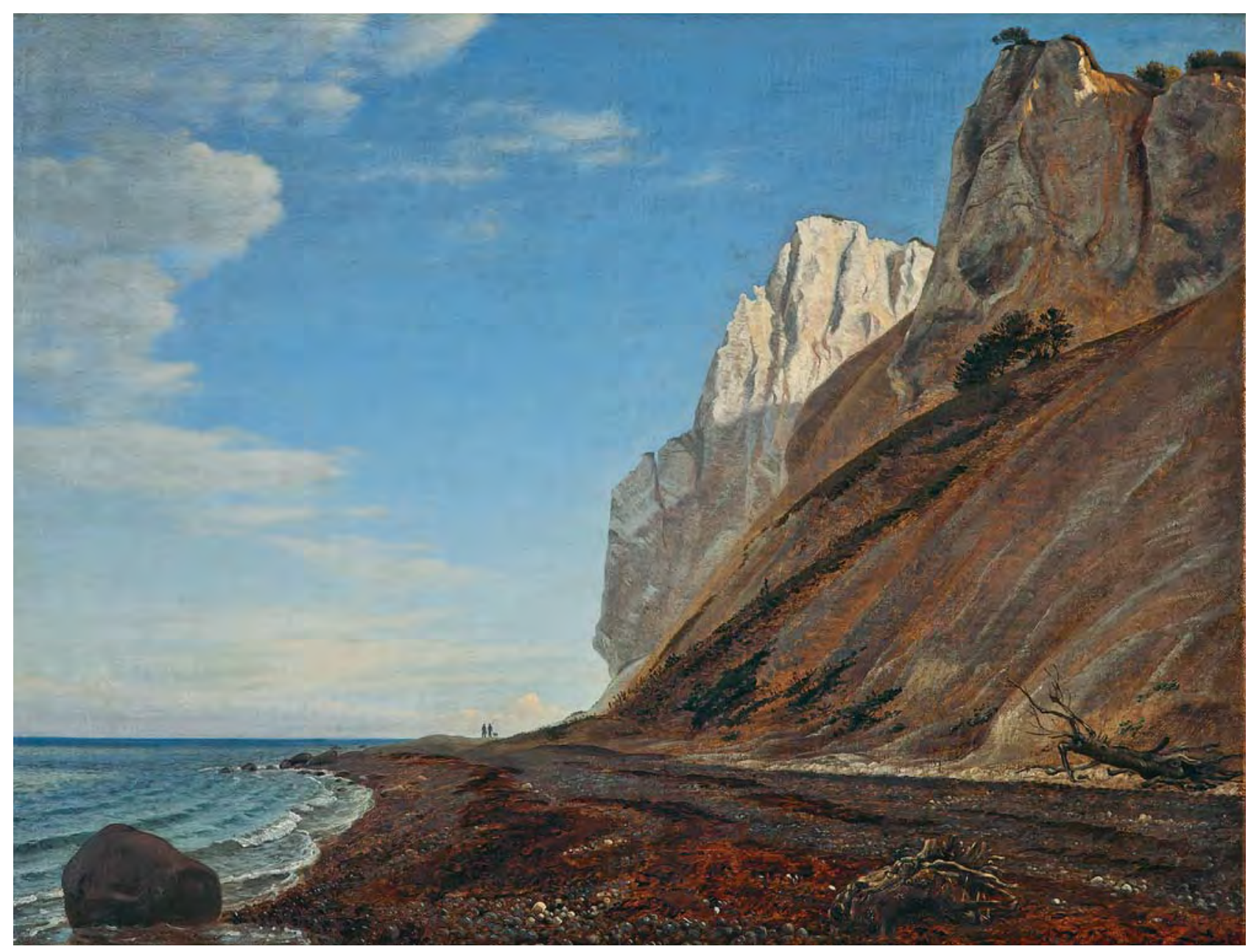

III. 13 [P. C. Skovgaard, View of Møns Klint, c. 1846.

Oil on canvas, 50 x $67 \mathrm{~cm}$. Fuglsang Kunstmuseum, Toreby, photo Ole Akhøj]

about 1841 until 1853 (Ohrt, 'Historien om et danmarksbillede'). The result was a number of works that ranged from the modest sketches to the often enormous formats of National Romanticism. The artist's many stays at Møns Klint took place during the years of the First Schleswig War, a fact which, however, had no direct consequences on his motives, although in a letter to his fiancée Georgia Schouw (1828-1868) Skovgaard writes:

There has never been a word about politics in your letters - what is happening in the world? How goes it with the war, the peace or the armistice? Today I have seen a real fleet of eight ships of the line, one frigate and probably also a brig coming from the east, and passing the cliffs, or rather Møn, towards Schleswig'. (Skovgaard 1850)

We see no warships in the Skovgaard pictures; on the other hand, in another picture from 1852, a steamer in the distance brings a message about the mod- 
ern world. ${ }^{19}$ Monrad's art collection, included a wonderful friendship portrait by Christen Købke (1810-1848) showing Constantin Hansen, and over the years Monrad built up an extensive collection of prints.

\section{The Democratic Space of the Forest}

The account of the genesis of Skovgaard's undisputed masterpiece, Beech wood in May, (1857; ill. 14) is one of the better elucidated stories in Danish art history (Oelsner and Grand, P. C. Skovgaard 55-112; Ohrt, 'En forsmag på Paradiset' 125-137). The commissioner of the picture was the principal of the school Borgerdydsskole in Christianshavn, Martin Hammerich (1811-1881). In 1841, Hammerich had married Anna Mathea Aagaard, a daughter of the judge Holger Halling Aagaard of the Iselingen Manor near Vordingborg in southern Zealand. Like the stockbroker Aggersborg, Hammerich wanted a landscape as a decoration for his home in central Copenhagen. Prior to the commission, Skovgaard had been on an extended study trip with his wife Georgia; the journey had taken them to Italy, where they stayed for some time in Venice, Livorno, Naples, Rome and other cities (Oelsner and Grand, P. C. Skovgaard 123-166).

Although he was far away from the domestic political upheavals, Skovgaard took a lively interest in the many political complications typical of the time. For example, whilst he was away he corresponded with Carl Ploug (1813-1894), who was not only a National-Liberal politician, but also the editor of the leading organ of the Liberal press, Fedrelandet [The Fatherland]: 'On 26th July the Ministry has surprised everyone with something called a People's Constitution, which is however nothing but a grand attempt to get rid of the Constitution and lead us back to Absolutism [....] now it must come to a serious struggle and final settlement, whether we are to continue to be a free people or go back to Absolutism because we do not understand how to use our freedom.' (Ploug, letter from 1854)

Skovgaard was not only one of the National-Liberals' favourite painters, he was, like them, fervently engaged in political life. When he journeyed home again in 1855, Skovgaard received a commission for the work, and shortly after his homecoming he went to Iselingen to make his preparatory studies. The subject of the picture was apparently quickly established. In a letter to Georgia, who had remained in Copenhagen, Skovgaard writes that he '[...] was so fortunate, on a Whitsun morning, to find the subject for the picture, and the Hammerichs are in complete agreement with my idea.'

Skovgaard found the subject for the picture in the woods behind the manor house. At the time, the Iselingen woods had a reputation as a model forest, in accordance with the prescriptions made by C. D. F. Reventlow (1748-1827) in the Forest Reserve Ordinance of 1805 . This ordinance was related to the great agrarian reforms. The impetus for these reforms was the bombardment of Copenhagen in 1801, which had left the country without a navy - and unfortunately also without the timber to rebuild one.

Only a small percentage of this area of the country consisted of forest; the communal use of the land, where both animals and people could draw on the 


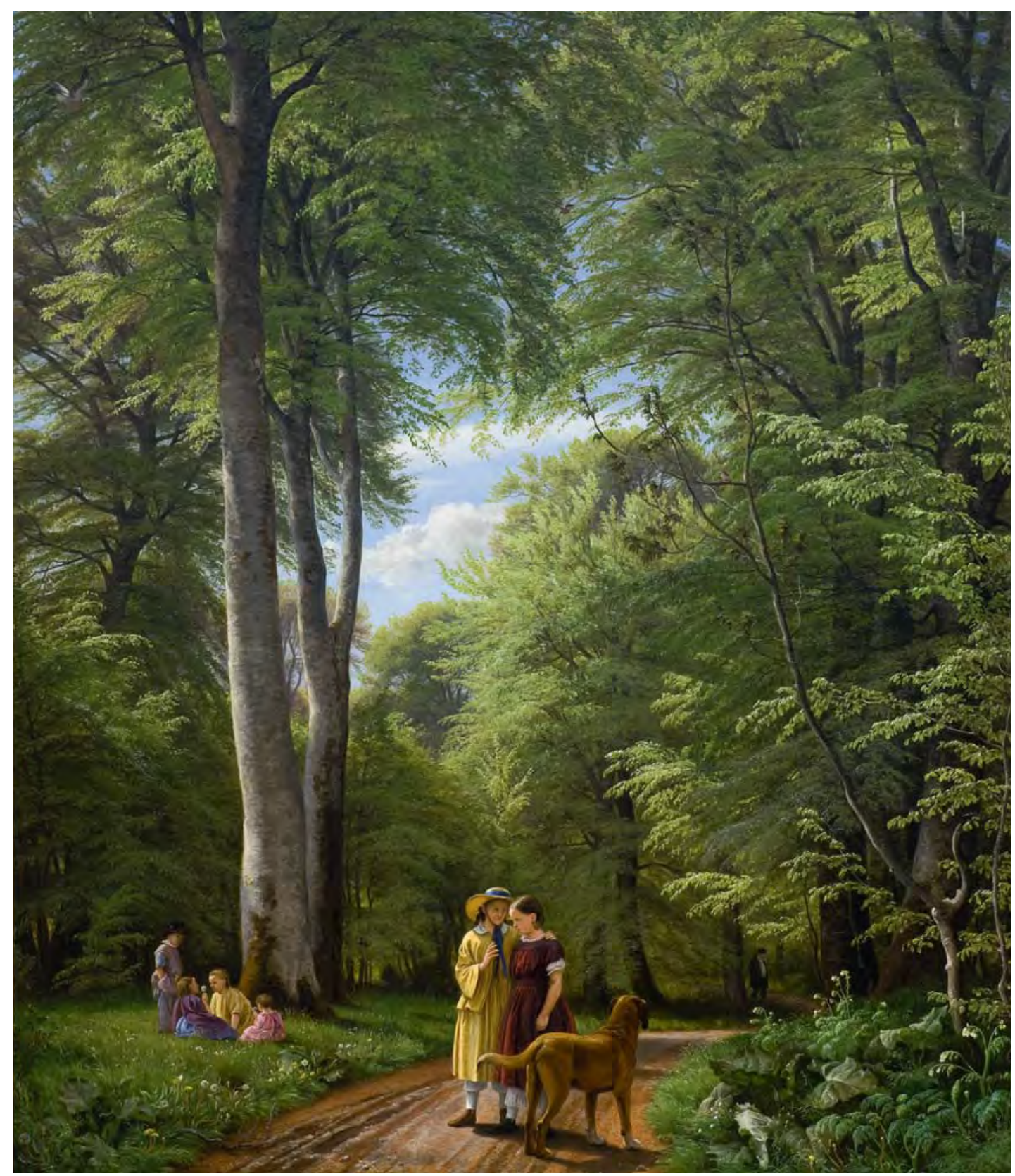

Ill. 14 [P. C. Skovgaard, Beech wood in May. Subject from Iselingen, 1857.

Oil on canvas, $189.5 \times 158.5 \mathrm{~cm}$. Statens Museum for Kunst, Copenhagen, photo SMK Foto]

resources of the forest, made its reproduction difficult. Timber had suddenly become a valuable political resource that was decidedly scarce in the Danish kingdom. This was to be remedied by the Forest Reserve Ordinance's regulation of access to forest areas, its protection orders and the fencing-in of the forests; and Iselingen, as mentioned, was one of the places where the interaction between these regulations and Ordinance's instructions for rational and economically sustainable forestry had most conspicuously borne fruit.

The tall, erect beeches in Skovgaard's picture speak their own clear language in this respect. Iselingen had succeeded in regenerating the forest so that the country could once more become a military and political power, which was very 


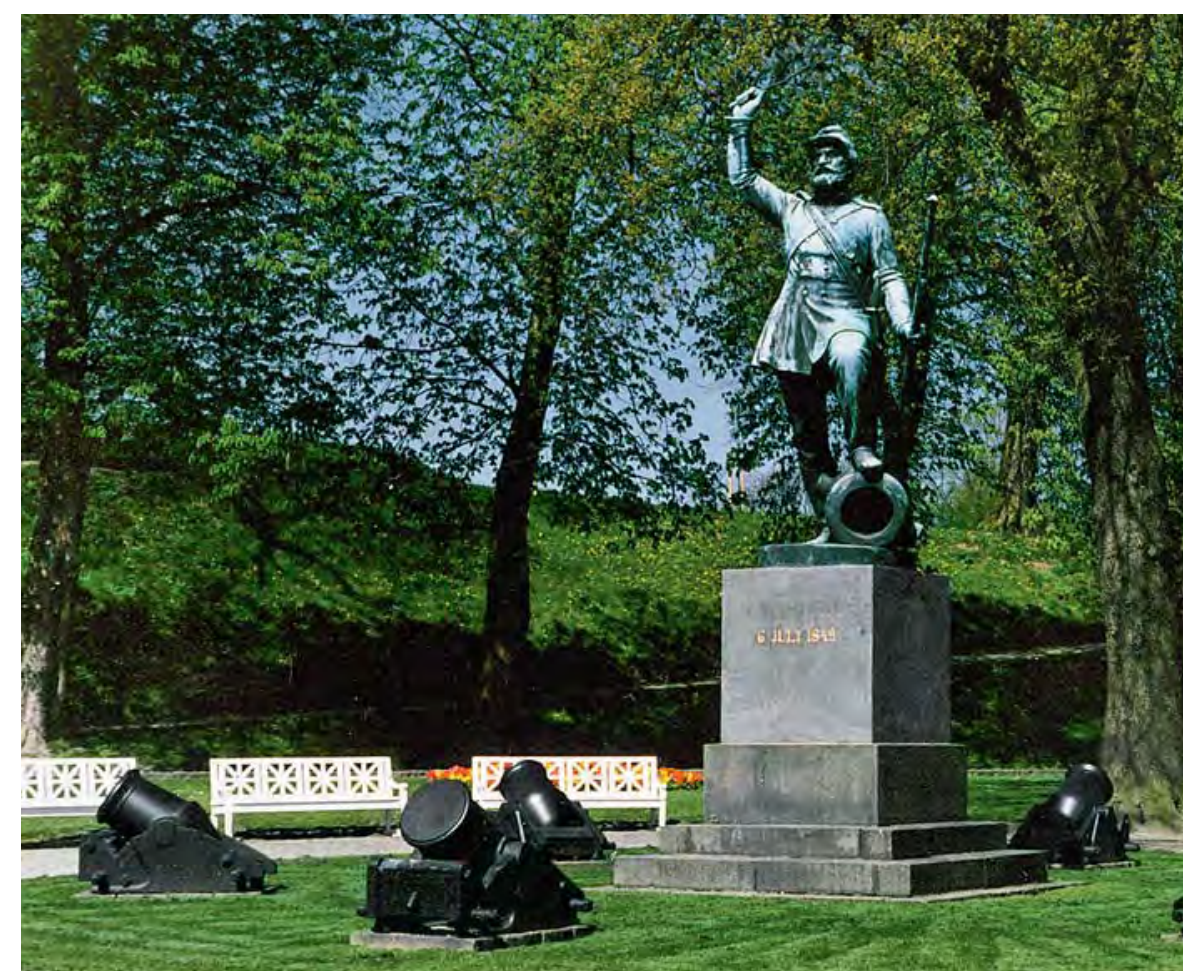

III. 15 [H. W. Bissen, The brave soldier after the victory, 1852-1858.

Bronze, height $375 \mathrm{~cm}$. Fredericia.]

important in the politically unsettled years between the two Schleswig Wars. The beeches rise skyward like soaring columns, ${ }^{20}$ and the full-crowned trees leave room for a modest glimpse of the Danish summer sky with its characteristic blue, shot through by passing cumulus clouds. We are in the month of May, and the forest has just developed its delicate green, still partly transparent foliage that lets plenty of light penetrate to the forest floor, where a gravel road links the groups of children in the foreground and middle ground with a single walking man in the background, presumably the estate owner Aagaard himself. The children in the picture are the commissioner's own children and two girls, cousins on the mother's side; the dog is the Broholmer Leo. As we have seen in some of the pictures mentioned earlier, here too the children are guarantors of the rebirth that is the overall theme of the picture, linking its several levels. Nature has just awakened; everything is greening and bursting forth, symbolizing the picture's hope of a new spring for the democratic politics that had been labouring under difficult conditions since their introduction in 1849 .

In this perspective, the beech plays an important role. Since the beginning of the century, the beech had been profiled with increasing impact as Denmark's national tree, a genuine image of the nation of Denmark. Molbech emphasized the beech as a hallmark of the beloved fatherland; Adam Oehlenschläger wrote about it in the text of the national anthem Der er et yndigt land [There is a lovely 


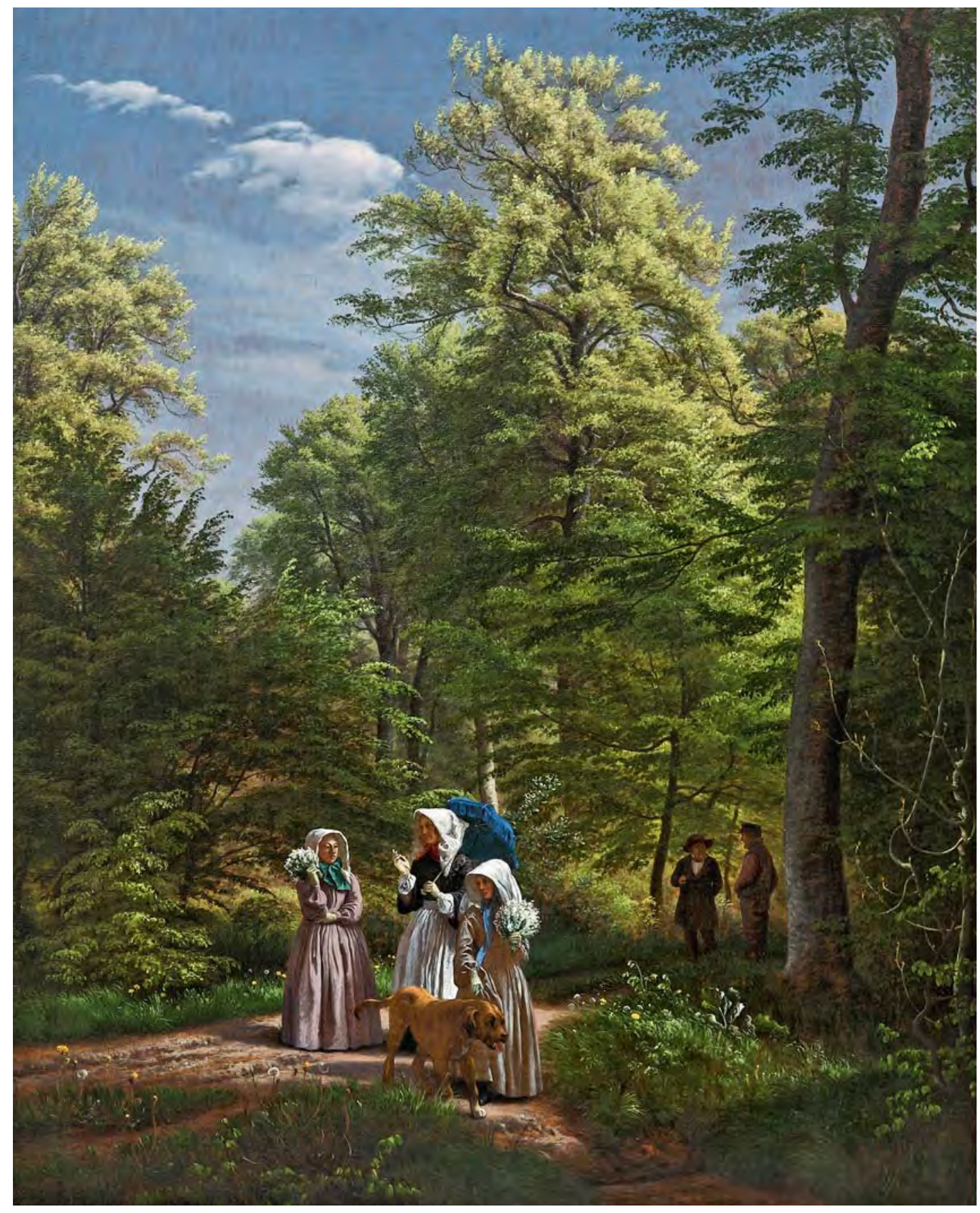

III. 16 [P. C. Skovgaard, View from Iselingen, 1861.

Oil on canvas, 122 x 98 cm. Fuglsang Kunstmuseum, Toreby, photo Ole Akhøj]

land] from 1816; we hear about the virtues of the beech from both the geologist Edvard Erslev and the botanist Christian Vaupell. Nor should we forget that the private soldier wields a beech branch as a symbol of victory in $\mathrm{H}$. W. Bissen's (1798-1868) monument Den tapre Landssoldat efter Seiren [The brave soldier after the victory], established in 1858 to commemorate Denmark's victory in the First Schleswig War (ill. 15).

In other words, the beech had been conventionalized as a symbol of the politically democratic Denmark, thus assuming the role of Denmark's national tree. 
In the process it had overtaken the oak, which had long taken precedence in this role. Over the years, Iselingen had been a sanctuary for the young NationalLiberal politicians. In Skovgaard's picture the democratic beech wood has grown strong at the expense of less viable and forward-looking forest regimes, which are visualized here in the form of the small stunted tree in the foreground, doomed to perish in the shade of the vital, upward-striving beeches. Half a century earlier, the Herder disciple Garlieb Merkel (1769-1850) had also used the forest as a metaphor for the republic: 'A republic is like a well cared-for forest. Each trunk strives upward with all its strength, stretching its arms, so long, so thick with leaves, as far upward and downward as its inner strength permits. All that is in its proper place flourishes, all that is diseased and defective dies' (Warnke 109).

This inherent evolutionary power in nature and society, which of necessity must bring forth constitutional, popular government at the expense of the absolute monarchy (symbolized here by the negation of the dead tree in the foreground by the beech), moreover seems to have had a certain resonance with the Hegelian ideas which, as we have seen elsewhere, permeated National-Liberal thinking. Of this both the commissioner of the picture, Hammerich, and the artist Skovgaard were undoubtedly fully aware; as, presumably, was C. C. Hall (18121888), who with his wife Augusta Mathea Hall, née Brøndsted (1816-1891) received their version of the woods at Iselingen in 1861 (ill. 16), where the combination of the dead tree and the vital beeches has been retained.

As Steen Steensen Blicher (1782-1848) said,

'Green is the festive array of spring, the colour of youth, of hope and joy. In the spring the Danish forests, fields and meadows grow green - and thus now unfolds, like the spring foliage of the beech, the hope of Denmark's rejuvenation into powerful popular life after the long, long, cold, cold political winter' (Blicher 458).

\section{Political Mapping}

In the above, the beech forest, hills and slopes have been investigated as expressions of the democratic efforts of the age, as have their origins in Juel's part patriotic idylls and part politicizing allegories of the time before and after the abolition of adscription. Together the many National-Romantic subjects from the widely ramified regions of the fatherland constitute a politically motivated mapping of the nation state of Denmark. At first these subjects were chosen from Copenhagen and northern Zealand, where the central administration was based; the movement radiated out to encompass the rest of Zealand and the islands, and finally also Jutland, which in time became a politically important issue that demanded its own visual iconography. Holstein and Lauenburg were hardly ever depicted - Schleswig appeared more frequently, but still relatively rarely. Among the artists who most persistently chose subjects from Jutland in the years between 1814 and 1864 were Vilhelm Kyhn and Thorald Brendstrup (1812-1883) (Oelsner and Bugge; Oelsner and Grand, Vilhelm Kyhn), but before them Martinus Rørbye (1803-1848) and Skovgaard had also visited the mainland peninsula and 


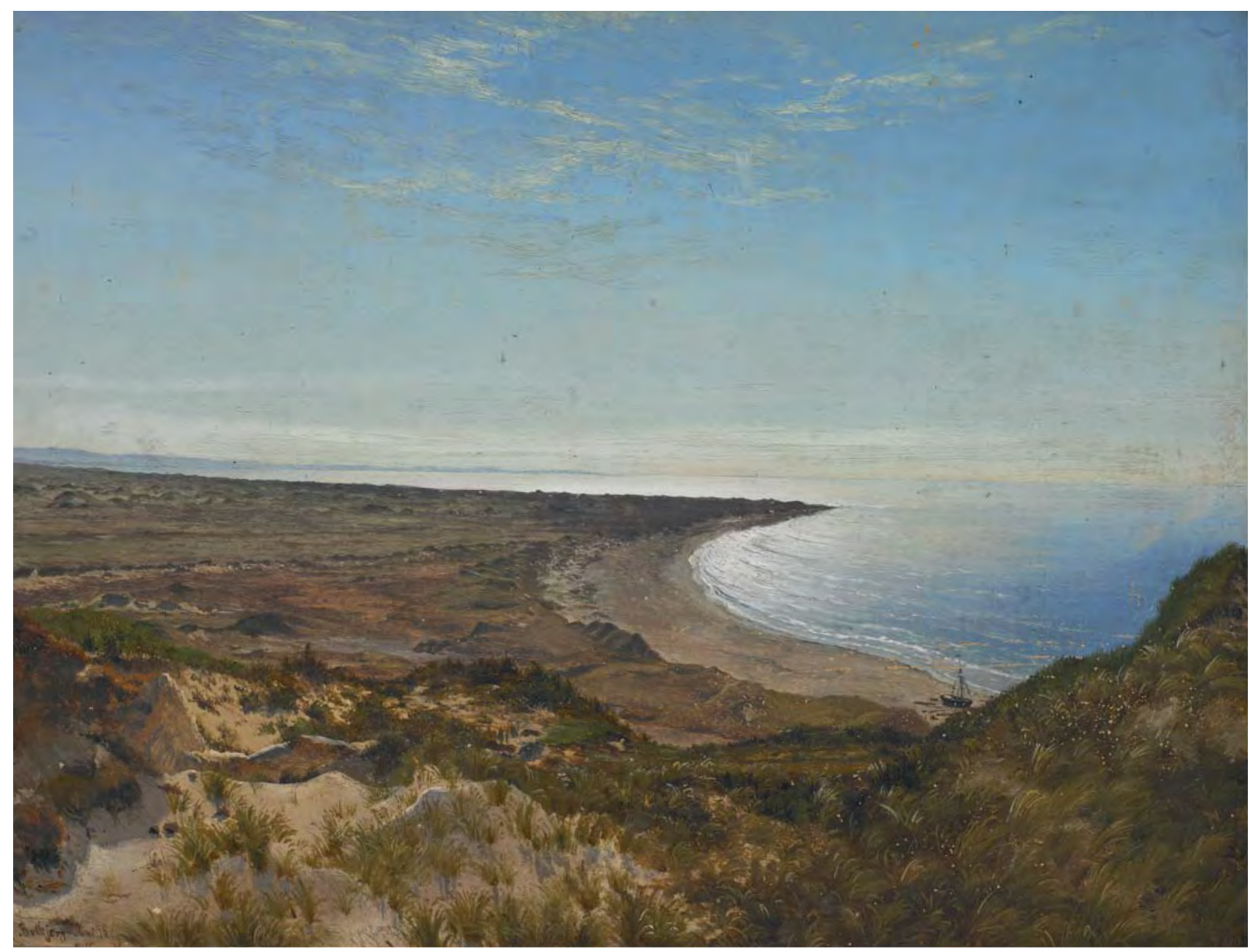

III. 17 [Vilhelm Kyhn, View of the sea, Bulbjerg, 1845.

Oil on canvas, $30 \times 41 \mathrm{~cm}$. Private collection, photo Knud Sejersen]

for a while incorporated Jutland in their range of subjects, although it remained parenthetical in their overall oeuvres. For Kyhn and Brendstrup, though, Jutland became something other than an artistic intermezzo, and it is therefore worth dwelling on this briefly. Kyhn's works are in this respect exemplary, View of the sea, Bulbjerg (1845; ill. 17) particularly so.

As is the case in several of the two artists' works, Kyhn has here chosen to show his subject from a greatly elevated viewpoint. We look down from a height along the coast at Bulbjerg, ${ }^{21}$ and this perspective makes the meeting of land and water, Jutland's outer, nation-defining boundary, the most important concern of the picture. Viewed thus, a considerable affinity can be found between landscape painting and the mapping of the country. The omnipresent topographer of the time, J. P. Trap (1810-1885), showed that he was aware of this during a visit to Denmark's eastern boundary, the Baltic island of Bornholm: 'From the platform of the tower one has an interesting geographical view of all of the land of Born- 
holm, both its rocky northern part and its flatter southern part, of the sea round it and across to Christiansø. Only a few times later have I enjoyed such a view where the surroundings lie like a map before one's feet' (Trap, 1966 246).

If one ascends high enough into the air, the encounter between land and water will almost inevitably meet one's gaze. These coastal boundaries also preoccupied the geographer Erslev in the book Den Danske Stat: 'It is the sea that makes our native land what it is [...] from almost any high point [one] can view the sea, and it therefore belongs to a Danish landscape, as much as mountains to a Swiss landscape. [...] But our sea is also very beautiful. True, if we except the North Sea, it is by no means as magnificent and mighty as the great ocean; on the other hand there is something so smiling and friendly about it, because it is cut into by these many tongues of land and islands. [...] It is well suited to these recent times in which the Dane has won praise and glory: it is behind the waves of the sea that we have lived in safety from others' (Erslev 1-2).

Kyhn, and with him Brendstrup and many of the other artists of the time, picked up the thread from Erslev's book: the history of Danish art abounds with pictures of the Danish coasts. However, they have rarely been inscribed in a political reading of the Danish landscape painting of the time. The panoramic landscapes, often with coastal subjects, that gave a nod to the age's ongoing mapping of the country became popular subjects in the period. We find them in the Academy exhibitions at Charlottenborg, and Kyhn's works were chosen for the Royal Art Collection by Høyen and Jürgensen Thomsen; but, more than this, artworks like these were to a great extent integrated into popular descriptions of the country. One example of this is the work Danmark, published by Emil Bærentzen's Lithographical Institute in 1856, in which the whole of the Danish kingdom within the framework of the 'Denmark to the Eider' program is portrayed in words and pictures. This and several other works of the period - particularly tellingly Trap's Statistisk-topografisk Beskrivelse afkongeriget Denmark (1858-1860) - contributed to the textual and pictorial mapping of Denmark that was called for in the years up to 1864 , when Denmark emerged in earnest as a defined nation state with a unified language, culture and history. This was a development to which the pictorial artists of the time, often at the urging of the National-Liberal politicians, had made their contribution. 


\section{Literature}

Allen, C. F. Breve fra danske Krigsmand. Copenhagen: Chr. Bruun, 1873.

Bagge, Povl et al., eds. Danske politiske Breve. Vol. 4. Copenhagen: Dansk selskab for fædrelandets historie og sprog, 1958.

Blicher, Steen Steensen. Udvalgte værker. Vol. 4. Copenhagen: Gyldendal, 1982-1983.

Damsgaard, Nina. Orla Lebmann og den nationale kunst. Vejle: Vejle Kunstmuseum, 1986.

Damsholt, Tine. Fadrelandskarlighed og borgerdyd. Copenhagen: Museum Tusculanums Forlag, 200.

Damsholt, Tine. 'En national turist i det patriotiske landskab'. Fortid og Nutid 1 (March, 1999): 3-26.

Davies, Douglas. 'The evocative symbolism of trees'. The iconography of landscape. Eds. Denis Cosgrove and Stephen Daniels. Cambridge: Cambridge University Press, 1988. 32-42.

Erslev, Edvard. Den danske Stat, en almindelig geographisk Skildring for Folket. Copenhagen: Kittendorff \& Aagaards Forlag, 1855-1857.

Fabienke, Tine Nielsen and Gertrud Oelsner, eds. Our best Pieces. Toreby: Fuglsang Kunstmuseum, 2008.

Frandsen, Steen Bo. Opdagelsen af Jylland. Aarhus: Aarhus Universitetsforlag, 1995.

Gelius, William and Stig Miss, eds. Under samme himmel. Land og by i tysk kunst 1800-1850. Copenhagen: Thorvaldsens Museum, 2000.

Glarbo, Henny. En Brevveksling mellem maleren Constantin Hansen og Orla Lehmann. Copenhagen: Fischers Forlag, 1942.

Grand, Karina Lykke. Dansk guldalder. Rejsebilleder. Aarhus: Aarhus Universitetsforlag, 2012.

Guldberg, Jørn. 'Danmark som billede. Naturvidenskab, historie og æstetik i Christian Molbechs "Ungdomsvandringer i mit Fødeland”. Udsigt til Guldalderen. Ed. Gertrud Oelsner and Iben Overgaard. Maribo and Viborg: Storstrøms Kunstmuseum and Skovgaard Museet, 2005. 65-75.

Hegel, Georg Wilhelm Friedrich. Forelasninger over historiens filosofi. Copenhagen: Gyldendal. 1997.

Henschen, Eva et al., eds. Johan Thomas Lundbye 1818-1848. ... At male det kjare Danmark. Copenhagen: Thorvaldsens Museum, 1994.

Holten, Susette. 'Et Patricierhjem fra forrige Aarhundrede'. Berlingske Tidende (1934-1935).

Howard, Luke, The Climate of London I-II. London: W. Philips, 1818-1820.

Hvidberg-Hansen, Gertrud, ed. Himlens spejl. Skyer og vejrlig i dansk kunst 1770-1880. Odense and Maribo: Fyns Kunstmuseum and Storstrøms Kunstmuseum, 2002.

Hvidberg-Hansen, Gertrud, Stig Miss and Birgitte Zacho, eds. Aftenlandet. Motiver og stemninger $i$ dansk landskabsmaleri omkring år 1800. Copenhagen and Odense: Thorvaldsens Museum and Fyns Kunstmuseum, 2011.

Jacobsen, Signe, ed. D.G. Monrad: en kunstsamler i 180o-tallet. Vejle and Nivå: Vejle Kunstmuseum and Nivaagaards Malerisamling, 1992.

Kold, Anders. 'Ej blot af lyst og i ledige stunder: to landskaber af Jens Juel på Thorvaldsens Museum'. Meddelelser fra Thorvaldsens Museum 1989. Copenhagen: Thorvaldsens Museum, 1989. 42-53.

Lehmann, Orla. Falstertalen. 30 January 1841. Web 16 May 2012. www.danmarkshistorien.dk.

Lehmann, Orla. Danmark til Ejderen. 28 May 1842. Web 16 May 2012. www.danmarkshistorien.dk.

Lehmann, Orla. Letter to P. C. Skovgaard, 21 April 1846. Skovgaard Museet.

Lundbye, J. Th. Et Aar af mit Liv. Introduction and notes by Mogen Lebech. Copenhagen: Foreningen for boghåndværk, 1967.

Mitchell, W. J. T. 'Imperial Landscape'. Landscape and Power. Ed. W. J. T. Mitchell. Chicago: The University of Chicago Press, 1994. 5-34. 
Molbech, Christian. Ungdomsvandringer i mit fodeland. Copenhagen, 1811/1815.

Nygaard, Bertel, 'Frihed, enhed og historie. Hegelianisme i dansk politisk kultur i det 19. århundrede'. Slagmark 50 (2007): 15-29.

Nygaard, Bertel. 'Civilisation, kamp og fremskrift i C.F. Allens Haandbog i Fodrelandets Historie'. Historie 1 (2009): 35-63.

Oelsner, Gertrud and Iben Overgaard, eds. Udsigt til guldalderen. Maribo and Viborg: Storstrøms Kunstmuseum and Skovgaard Museet, 2005.

Oelsner, Gertrud and Ingeborg Bugge, eds. Thorald Brendstrup. I guldalderens skygge. Aarhus: Aarhus Universitetsforlag, 2012.

Oelsner, Gertrud and Karina Lykke Grand, eds. P.C. Skovgaard. Dansk guldalder revurderet. Aarhus: Aarhus Universitetsforlag, 2010.

Oelsner, Gertrud and Karina Lykke Grand, eds. Vilhelm Kyhn \& det danske landskabsmaleri. Aarhus: Aarhus Universitetsforlag, 2012.

Ohrt, Nils. 'Historien om et danmarksbillede: P.C. Skovgaard og Møens Klint'. Møen i dansk kunst. Ed. Claus M. Smidt. Nivå: Nivaagaards Malerisamling, 1994. 23-44.

Ohrt, Nils. 'En forsmag på Paradiset'. Udsigt til guldalderen. Eds. Gertrud Oelsner and Iben Overgaard. Maribo and Viborg: Storstrøms Kunstmuseum and Skovgaard Museet, 2005. 125-137.

Ploug, Carl. Letter to P. C. Skovgaard. 16 August 1854. Skovgaard Museet.

Ritter, Joachim. 'Landskab'. Estetiske Teorier. Ed. Jørgen Dehs. Odense: Odense Universitetsforlag, 1995. 23-50.

Skovgaard, P. C. Letter to Georgia Schouw. 11 June 185o. Skovgaard Museet.

Skovgaard, P. C. Letter to Orla Lehmann. 25 July 1853. Rigsarkivet.

Trap, J. P. Statistisk-topographisk Beskrivelse af Kongeriget Danmark. Copenhagen: G.E.C. Gad, 1858-60.

Trap, J. P. Fra fire kongers tid 1-3. Copenhagen: G.E.C. Gad, 1966.

Ussing, J. L., ed. Hoyens samlede Skrifter. Copenhagen: Thieles Bogtrykkeri, 1871.

Vaupell, Chr. De danske Skove. 1863. Randers: Nabu Press, 1986.

Wamberg, Jacob. 'Kunstens landskaber. En lille mentalitetshistorie'. Landskab. Meddelelser fra Ny Carlsberg Glyptotek. Vol. 7. Ed. Anne Marie Nielsen. Ny serie 7. Copenhagen: Ny Carlsberg Glyptotek, 2005. 9-23.

Wammen, Hans. Den tomme stat. Copenhagen: Museum Tusculanums Forlag, 2011.

Warnke, Martin. Political Landscape. The Art History of Nature. Cambridge, MA: Harvard University Press, 1995.

Weinwich, N. H. Maler-Billedhugger-Kobberstiks-Bygnings og Stempelskjarer Kunstens Historie i Danmark. Copenhagen: Johan Frederik Schultz, 1811. 


\section{Notes}

1 It should be noted here that the concept of the 'Danish Golden Age' is widespread in Danish art history, where the term is normally used to designate the epoch c. 1800-1850. The Golden Age concept has had its greatest impact on the internal Danish context; the same period is often called 'Biedermeier' in the German-speaking world. In the English-speaking world the term 'Romanticism' is used, and in Denmark the literature of this time is usually referred to as Romantic; but since the subject of this article is a survey of the period's visual-art idiom in Denmark, the term 'Golden Age' is retained here.

2 This mode of thinking found its premises to some extent in ancient Greece. On this, see Damsholt, Fadrelandskarlighed 93

3 In the work of J. C. Dahl (1788-1857) and C. W. Eckersberg, among others, we find a suite of subjects that seem closely related to Molbech's. This is true of several of Dahl's subjects from southern Zealand and Eckersberg's Møn pictures.

4 At first, the National-Liberals were not a true party with a related electoral program, but a group of like-minded people who were united in their struggle for the abolition of absolutism and a democratic constitution. For more on this see Wammen.

5 Among the influential lectures are 'Om betingelserne for en skandinavisk Nationalkunsts Udvikling' [On the conditions for a national art], given on 23rd March 1844, and 'Om national Kunst' [On national art], given in 1863 .

6 See Bagge et al. 295-296. It should be remarked that Høyen's name featured on a list of candidates who were presumably willing to be elected.

7 Skovgaard was not the only one to enjoy the patronage of the stockbroker Aggersborg, who bought several works by other contemporary artists. See Holten.

8 After a visit to the top of Goose Tower Molbech wrote: 'a region where harbour and land and forest in the closest union and most perfect harmony form a glorious picture, in which it seems all of Denmark's natural beauty is reflected.' Quoted here from Guldberg 70.

9 It should also be mentioned that the Goose Tower was the object of one of the first heritage preservation cases in Danish history. As part of the work of the Royal Commission for the Preservation of Antiquities, the Goose Tower, which until 1808 belonged to a Mrs. Rejersen, was then transferred to the Crown as a protected building.

10 There are several indications of how the Goose Tower became part of the cult of the past that typified the age, inspired not least by Herder's linkage of culture, language and history. In 1816, the poet Adam Oehlenschläger wrote of Valdemar's Tower, as it was then called: 'In the dusk we walked out to Valdemar's Tower; and it pleased me so see this ancient stone ruin, the oldest in the kingdom, in the twilight, looming like a great black giant while the present was hidden in a light mist. One can walk up into the tower. The previous owner has presented it to the Crown. If it were mine I would have a chamber up there. There, Snorri Sturlusson, and Saxo Grammaticus, and the old heroic ballads, would lie in beautiful vellum bindings; and there I would read them, and drink beer from a Golden Horn in the afternoon.” Quoted from Oelsner and Overgaard 99.

11 A motif we also find in P. C. Skovgaard's work, in his Bleaching ground beneath large trees, 1858. Oil on canvas, 44.5 x $36.5 \mathrm{~cm}$. Statens Museum for Kunst, inv. KMS3772.

12 Hegelianism has as a rule been understood in relation to Johan Ludvig Heiberg, Hans Brøchner and Hans L. Martensen, but as Bertel Nygaard shows, National-Liberal politics were based on a Hegelian foundation. On this, see Nygaard 15-29. 
13 Letter from Constantin Hansen to Orla Lehmann, dated 9 July 1855 . Skovgaard had just come home from his long journey abroad and had been commissioned to paint the large Beech wood in May for Martin Hammerich. The letter is reproduced in Glarbo, 96-97.

14 In 1855-1857 the geographer Edvard Erslev published Den danske Stat, en almindelig geographisk Skildring for Folket, in which he reviews the distinctive characteristics of the Danish landscape in a highly political manner. Erslev also discussed the Danish climate, giving us to understand that in summer the weather is capricious and mutable, and that cloudless days are rarities in Denmark. It is characteristic of painters from the Danish Golden Age that they take a detailed, accurate approach to the given weather conditions; they presumably also drew inspiration from the English meteorologist Luke Howard who in 1818 published the two-volume work The Climate of London, in which he drew up a systematic account of various cloud types which is used to this day, with a few variations and additions. For more on this, see Hvidberg-Hansen, Himlens spejl.

15 One might wonder about the plants on the ancient barrow, since the Antiquities Commission was tasked with preserving and protecting the country's many ancient monuments from exploitation. As far as I can see, though, there is no doubt that this is an ancient burial mound, marked by the telling stone circle.

16 The next year, 1847, Høyen backed up Lehmann's ideas by founding the Society for Nordic Art.

17 Discussed in Allen. The representatives of the Danish artists were hardly coincidental: they all belonged to the group of artists whose work Orla Lehmann, through purchases and commissions, incorporated in his private collection. Besides the above-mentioned works by Skovgaard and Constantin Hansen, Lehmann owned at least two works by Jørgen Sonne; details follow. Midsummer Eve. Peasants who have lit a bonfire on a burial mound dancing around the fire, 1860. Oil on canvas, $103.5 \mathrm{x}$ $143.5 \mathrm{~cm}$. Statens Museum for Kunst, KMS 3780. The Battle of Fredericia, 6th July 1849. After the enemy batteries have been taken and the battle won, during the pursuit the Danish troops come upon an enemy artillery park at Heise Inn, 1849, [watercolors]. Pencil on paper, 320 x $780 \mathrm{~mm}$. Museum of National History at Frederiksborg, inv. A4939.

18 Letter from D. G. Monrad to Emilie Monrad, dated 29 January 1848, repr. in Bagge et al. 38. The rejected picture mentioned is presumably a view from the Jægersborg Deer Park, discussed in Jacobsen 42

19 See P. C. Skovgaard, Prospect of Møn's Klint, 1852. Oil on canvas, 126 x $190 \mathrm{~cm}$. Fuglsang Kunstmuseum, Toreby. In Dansk guldalder. Rejsebilleder, Karina Lykke Grand also includes a discussion of the significance of the infrastructure for the travel patterns of these artists.

20 The column metaphor could profitably be researched in relation to the period's interests in antiquity and its democratic forms of government. Unfortunately there is no room for this analysis here.

21 In the years between 1840 and 1842 Bulbjerg hosted the so-called Bulbjerg Rallies, which were inspired by Steen Steensen Blicher's Himmelbjerg Rallies. 